
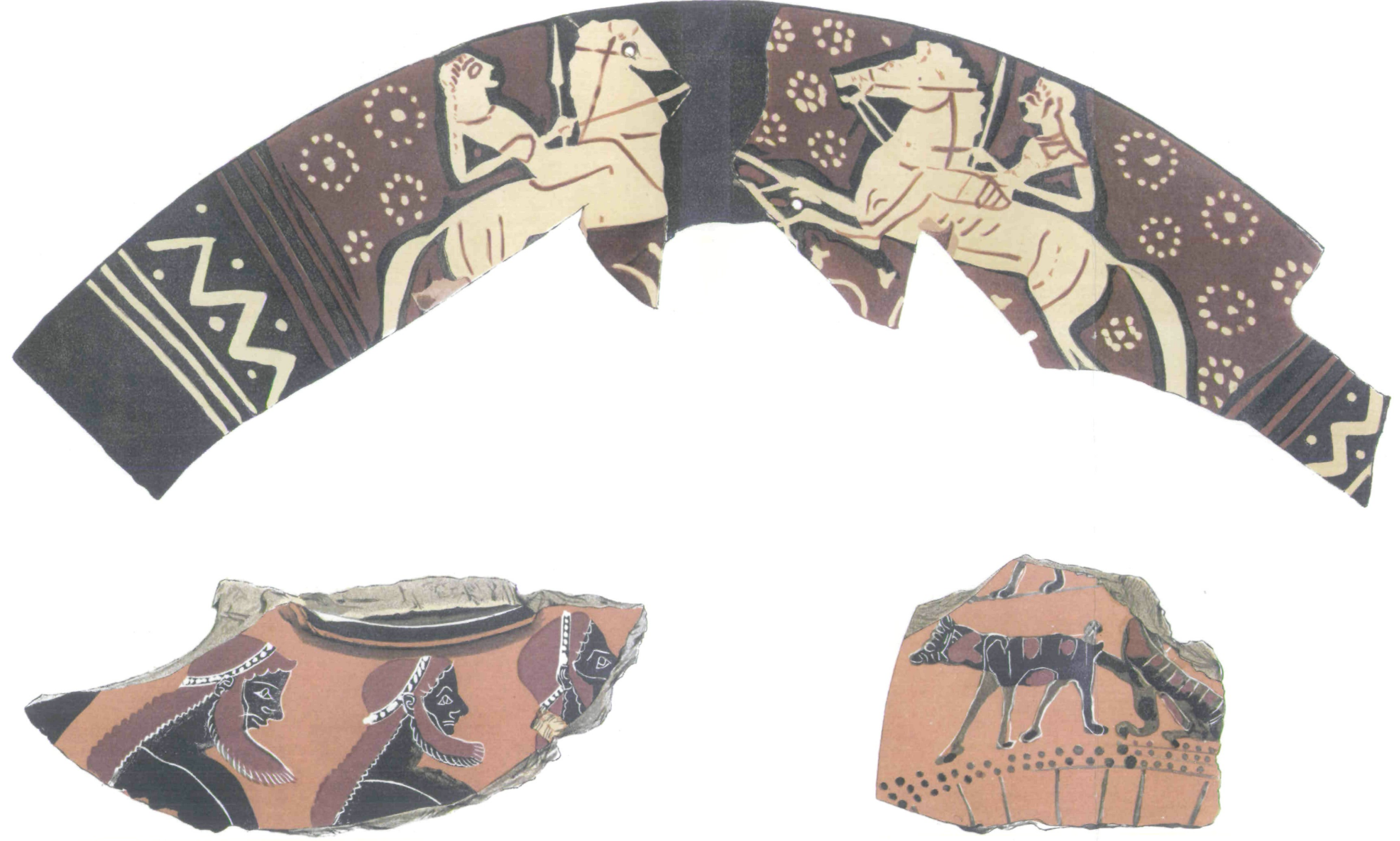

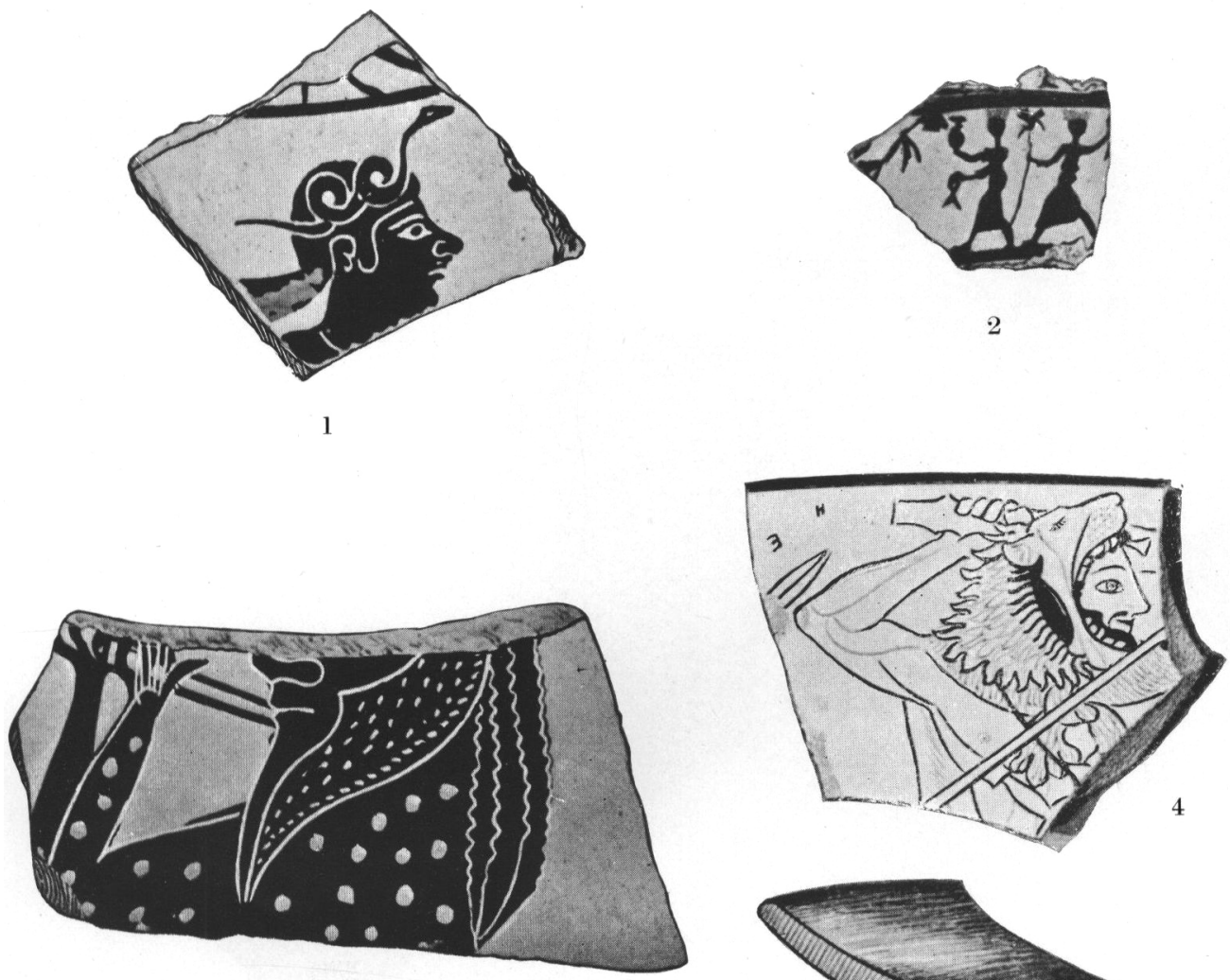

3
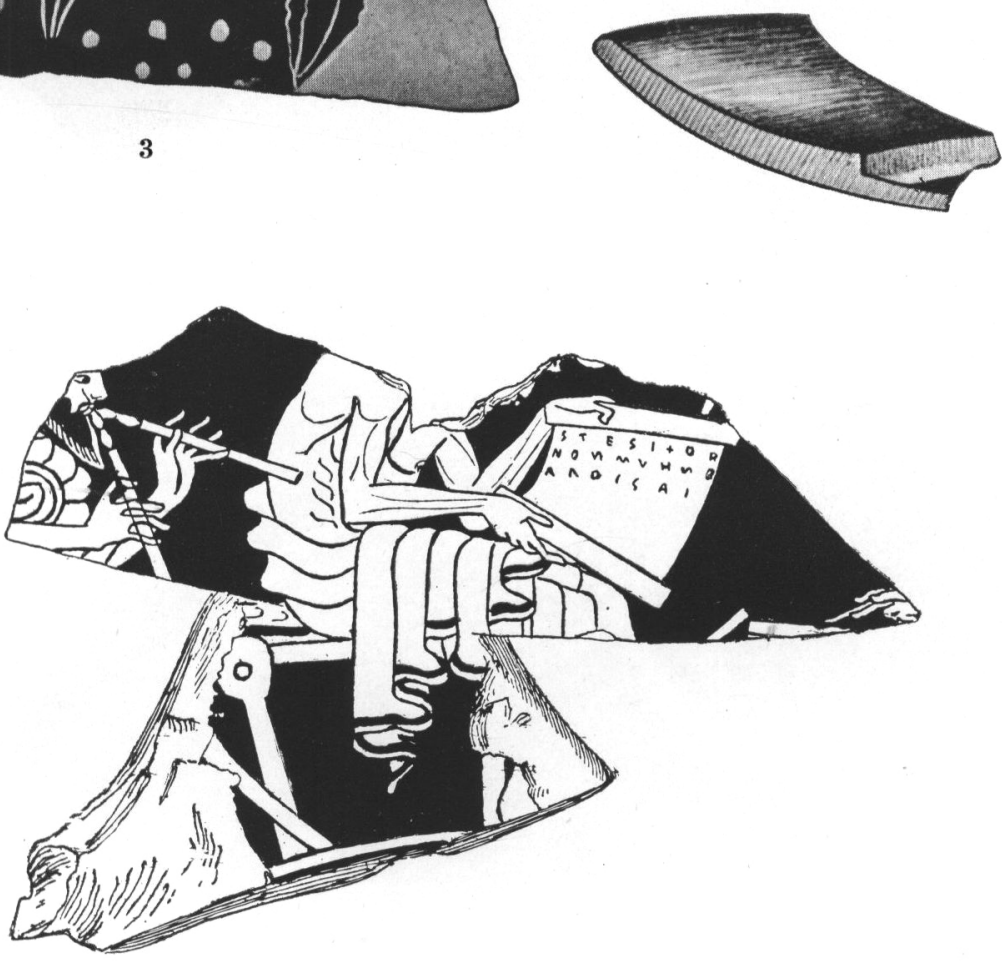

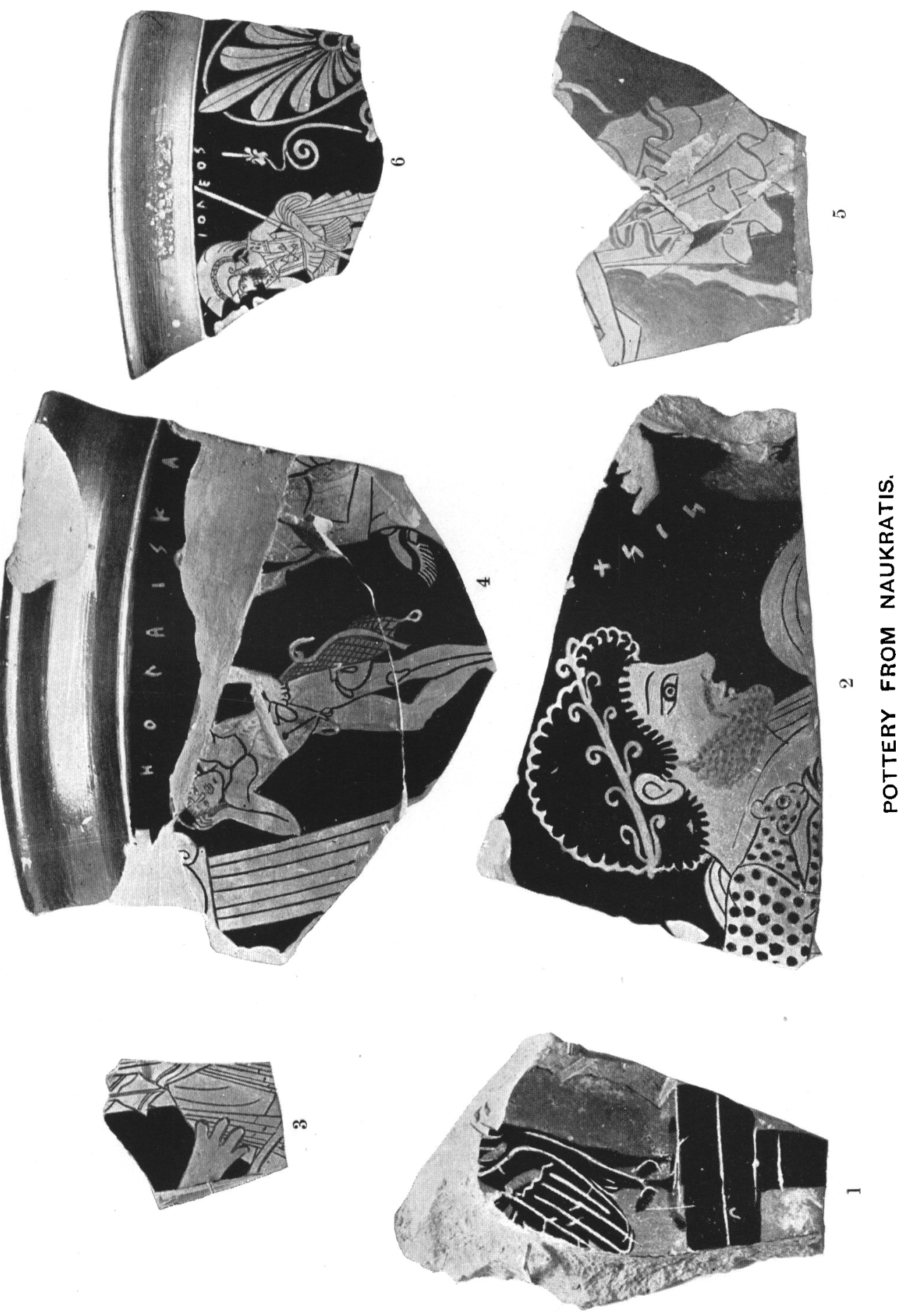
NAUKRATIS, 1903.

IN the spring of 1903 I was enabled by a grant from the Craven Fund of the University of Oxford to return to the site of Naukratis. Having left certain parts of the Mounds unexplored in $1899^{1}$ because they were either too high, or too sodden with the infiltration of water, I intended to attack them whenever the sebrakh diggers should have removed the unproductive upper layers, and a season of low Nile level had occurred. The results of this campaign, the last, I expect, that will be undertaken at Naukratis, I embody in the following Report, discussing at the same time certain points on which new light can be thrown from other sources.

\section{A.-The Site.}

The identification of the site of Naukratis, so brilliantly made by Mr. Petrie, has never been questioned. All scholars agree, moreover, with his contention that Naukratis lay to west, not east, of the Great or 'Agathodaemon' Nile of Ptolemy. Mr. Petrie, however, maintained that the town did not lie actually on that river, but on a derived Canal. His grounds were these. (1) Herodotus (ii. 97) says that during the Inundation there was water passage from Naukratis to Memphis under the Pyramids: but that the usual way lay by the apex of the Delta (i.e. by the river itself): (2) Strabo (xvii. 23), after mentioning the Nitriote Nome in the course of a geographical

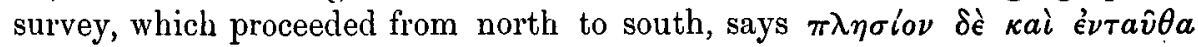

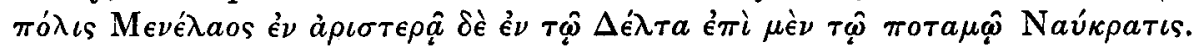
This statement, said Mr. Petrie, in that it placed the town on the left bank of the river, was the result of a confusion in Strabo's mind. For, in fact, Naukratis was on the right of the Canopic Nile as one ascends. Strabo should have said on the left of a derived Canal.

In this interpretation of his authorities, the argunents for which failed at the time to convince his colleague, Mr. Griffith, ${ }^{2} \mathrm{Mr}$. Petrie seems to have

\footnotetext{
${ }^{1}$ See B.S.A. vol. v. pp. $26 \mathrm{ff}$.

2 Nauk, ii. p. 83. I do not agree with Mr. Griffith's argument either, though I come to his conclusion. I see to reason for placing
}

Nankratis on the East of the river, not supposing 'Delta' as used by Strabo to mean only the land between the rivers : and the fact that Ptolemy put the Nome of Naukratis on 
been wrong. Herodotus in expressly stating that the route viâ the Pyramids existed only in Inundation time, and that the usual route was by the river, supplies no ground for assuming the existence of a canal. Nor does Strabo. In the passage quoted above, the latter, I have no doubt, meant by é $\nu \dot{a} \rho \iota \sigma \tau \epsilon \rho \hat{\alpha}$, to left, not of the river, but of the Nitriote Nome and Menelaus, to which he had just conducted his readers. From that digression into the western desert he returns eastward (i.e. to the left hand) to the Delta (by which he probably understood, as we do now, not only the area between the Niles, but the whole fan of irrigated land) and clearly states that Naukratis lay on the River. To the ordinary authorities, which support him in this, may be added the Coptic recital of the Martyrdom of the Blessed Epimachus, edited and translated by F. Rossi, ${ }^{3}$ wherein the Saint is brought to 'the place called Naukratis and there remained on the river.' On the great stela of Nectanebo discovered upon the site of Naukratis in 1899 (published by G. Maspero and commented on later by Messrs. Erman and Wilcken ${ }^{4}$ ) it is enacted that the stone be set up in Naukratis on the bank of the $A n u$ (' $n w)$ stream, i.e., without doubt, on the bank of the Great River.

\section{(1) Foundation.}

\section{B.-History.}

The question whether Naukratis existed before the settlement of Greeks there by Amasis (circa 570 B.c.) is still open : but a new aspect has been given to it by facts not sufficiently considered in the original controversy between Messrs. Petrie and Gardner on the one hand ${ }^{5}$ and G. Hirschfeld on the other, ${ }^{6}$ or in the résumé of M. Mallet. ${ }^{7}$ Attention was drawn repeatedly in B.S.A. vol. v. ${ }^{8}$, as a result of the excavations of 1899 , to the distinctively Egyptian character of the southern half of the Mounds; and among other inferences, the suggestion was once more made ${ }^{9}$ that there was a distinct Egyptian town on the site which existed before 570 B.c. The first part of this suggestion found almost immediate support through the discovery of the stela of Nectanebo, already mentioned (it came to light almost in the centre of the southern area called by Mr. Petrie 'The Great Temenos'); for this speaks of the place under an Egyptian name, Pi-emrô, ${ }^{10}$ adding 'called Naukratis.' But an inscription of the fourth century has,

the East does not justify Mr. Griffith in saying that although Ptolemy expressly stated the town was on the west, he was really picturing it to himself as on the east! It is worth notice that, in the Revenue Papyrus of Philadelphus, there is no Naukratite Nome, but Naukratis itself is attached to the Saitic, evidently as a place not in the Nome, but near

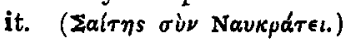

3 Pap. Coptidel Museo Torinese in Mem. R. Accad. Scienze Torino, 2nd Ser., vol. xxxviii. pp. 271-298.

${ }^{4}$ C. R. Acad. Inser. 1899 : Cairo Museum
Cat.: Zeitsch. für Ägypt. Sprache 38, part 2, p. 127.

5 See esp. the former's letter to the Academy, July 16, 1887 ; and the latter's remarks on p. 71 , and elsewhere of $N a n k$. ii.

${ }^{6} R$. Iirus. 43, p. 209.

7 Mém. Mission du Caire, 1893.

${ }^{8}$ See esp. pp. 45-48.

9 It was made in Smith's Dict. Geog. s.v. and was repeated by Mallet, op. cit. p. 150.

10 Erman, l.c., but according to Maspro, Pa-meraiti. 
of course, but little bearing on the second part of the suggestion, viz. that such a town existed in the sixth, seventh, or earlier centuries.

The excavations of 1903, however, while fully confirming the distinction of the site into a northern Greek quarter and a southern Egyptian quarter, also tended to support a suggestion first made by Mr. Petrie, ${ }^{11}$ that the south part of the site was the earliest occupied. The thick burnt bottom stratum, which Mr. Petrie dated before all other human remains on the site, was found wherever we sank pits between Mr. Petrie's 'Scarab Factory' and his 'Great Temenos,' but nowhere either north or south of this area. In a series of pits, which I pushed southward from the southern edge of the central excavated area up to and even within the southern limit of the "Great Temenos' area, the basal mud occurred at an average depth of 5 feet. Upon it, varying from one to two feet in thickness, lay this burnt stratum of charcoal and ash, containing no sherds but rougn ' kitchen' ware in which I fail to detect any necessarily Greek character: while the two undisturbed feet of deposit superincumbent contained a little painted white-faced Naukratite pottery (such as that which lies in the bottom stratum on the north) and black-figured sherds, and abundance of fragments of figurines and amulets in the same glazed 'sandy ware' as that described by Mr. Petrie (Nauk. i. p. 14). The uppermost stratum was naturally a hotchpotch of disturbed stuff, among which, however, occurred only a very small amount of Greek sherds. This region has been the scene of a conflagration, which devastated but a small area, and may either have been accidental or kindled with intent to effect a certain clearance.

The glazed 'sandy ware' objects, which are the rarest of finds at the north end of the Mounds, but on the south the most frequent, at whatever point a pit is sunk, occurred with these scraps of the earliest painted Naukratite vases, but also at a lower level than the latter were ever found. The beginning of the fabric must therefore be dated before that of the local painted pottery of Greek manufacture. It had been a flourishing industry for some time before the latter began, but it. flourished in the south of the site only.

To show how the classes of remains differ at the two ends of the site, I quote from my day book that on May 1st and 2nd, while digging exclusively in the southern quarter, Mr. Edgar and I found five Egyptian bronze figurines : fragments of three faience bowls with incised patterns and hieroglyphics : two stone figurines, Egyptian style: one alabastron : seventy-three glazed sandy ware Egyptian cult figurines or amulets : and seven painted Greek sherds. Whereas in the three weeks during which we dug out the north end, and there found so much Greek painted ware that after wholesale rejection we had to pack nearly a thousand specimens, we came across no Egyptian bronzes; no incised faience; and under twenty objects, all told, in glazed 'sandy ware.'

It is not necessary to insist further on this distinction between the north

11 Nauk. i. p. 21, but somewhat unaccountably contradicted by Mr. Gardner, Nauk. ii. p. 34. 
and south towns, between Pi-emrô and Naukratis. It was sufficiently set forth in B.S.A. v., and indeed was indicated in the Memoirs of Messrs. Petrie and Gardner themselves. But, if it be conceded also (as seems inevitable) that the Egyptian end of the site was the earliest inhabited, then the arguments of those gentlemen, claiming an earlier date than 570 for the Greek settlement, on the ground that there is evidence of prior settlement on the site itself, lose their cogency : for that evidence refers, not to the Greek, but to the Egyptian town. I need only call further attention to Mr. Edgar's argument, stated in B.S.A. v. p. 49, that the glazed 'sandy ware,' if not Egyptian, was probably a Phoenician and certainly not a Greek fabric-an argument which has not been assailed.

Although, however, the Egyptian town was the earlier, the contention that Greeks were settled on some part of the site before 570 is not disposed of, if it can be supported on grounds independent of the earlier remains in the southern Mound. The literary argument stands where Hirschfeld, Gardner, and Mallet left it, except for this fact-that if there were a previous Egyptian town, Herodotus' phrase in regard to Amasis' settlement, roî

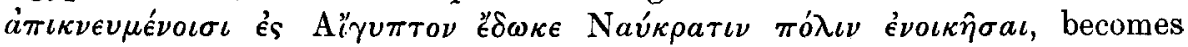
intelligible, without assuming the previous presence of Greeks (cf. Nauk. i. p. 4 and ii. p. 71). The epigraphic argument of Mr. Gardner has not been re-asserted during the past five years against the destructive criticism of Mr. Edgar (B.S.A. v. p. 52), and has not received any support from the inscribed sherds found in either of the later excavations.

On the whole, however, though agreeing with Hirschfeld that the state-

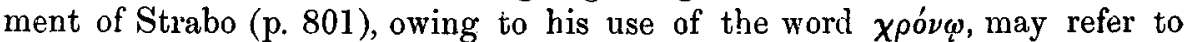
so long a space of time as to be quite reconcileable with the Herodotean date, I see no adequate reason for rejecting the previous presence of Milesians on a small part of the site later devoted to a general Foreign Concession. There is some, if very little, independent positive evidence for it (of an inferential sort) in the statement which Jerome repeated from Castor, and in the tale of Polycharmos, cited by Athenaeus (xv. 18); while there is no direct evidence proving a negative.

(2) Vicissitudes.

(a) Mr. Petrie's argument that the town suffered a great general disaster early in the sixth century (which he ascribed to the troubles attendant on the succession of Amasis) was based on (1) the existence of the burnt bottom stratum, (2) the sudden cessation of the scarab manufacture at the opening of the reigu of Amasis. It is greatly weakened by our observation (which nothing in his own excavation-notes contradicts) that the burnt stratum is limited to a small area; and by Mr. Edgar's probable suggestion that the scarab manufactory, being a Phoenician affair, ceased (if indeed it did cease) ${ }^{12}$ on the concession of a part of the site to the Greeks

\footnotetext{
12 The argument from the absence of Amasis
} cartouches is, as Mallet showed, a very weak 
by Amasis. For this concession may reasonably be supposed to have excluded other foreigners. On the whole, therefore, it is unnecessary to assume any more cataclysmal event at this period than the disturbance of other aliens by the Greeks settled under the terms of Amasis' concession, which I still regard as a measure of compulsion and restriction rather than favour.

(b) The argument stated in B.S.A. v. p. 36 that there was no subsequent interruption of Naukratite prosperity was not supported by the observations made in 1903. Mr. Gardner, who judged, from the state in which he found votive objects distributed round the southern Aphrodite Shrine, that 'some calamity befell the city' (during the Persian invasion under Cambyses) seems to have been right, although other causes might have led to the breaking and casting forth of dedicated vessels. There is clear evidence that the structures in the Northern Temenos, which I name the Hellenion, were restored practically from the foundation in the first half of the fifth century. (See below, p. 114.) The first explorers argued from their failure to find good red-figured pottery. This negative observation has been weakened by the sherds unearthed in 1899, and still more in 1903. Red-figured ware of several periods and of all qualities, including the very finest, occurred in the northern Temenos; as also did the later varieties of black-figured ware. But imported red-figured ware of the early period of severe style was, in fact, foun'l very rarely; and this fact points to an interval of commercial stagnation having taken place in the first half of the fifth century before the visit of Herodotus.

(c) A general Ptolemaic restoration, involving the rebuilding of the northern shrines on artificial mounds of sand, heaped over their ancient sites, is certain. But, as was said in B.S.A. v. p. 37, this may be supposed to have been due not to the city having fallen to ruin, and much less to its having lain in ruin for any length of time, but simply to the well known Ptolemaic policy of renovating; almost refounding, cities and shrines throughout Egypt as a justification of the new Dynasty. This, as before suggested, had to be done at Naukratis in a thoroughgoing way, probably owing to rising damp. As will be stated more in detail when we come to speak of the Hellenion, a belt of unproductive sand was found to overlie remains ranging from the first balf of the sixth to the latter half of the fourth centuries, many of which, notably those of an architectural nature, had obviously been bedded down to receive the sand. Above this belt were found the pavements and walls of a connected series of chambers, in which nothing pre-Ptolemaic occurred.

\section{(3) Extinction.}

The disappearance of Naukratis has certainly been dated by Mr. Petrie too early. His argument that, after a period of revived prosperity under the Ptolemies, the city decayed rapidly under the Empire, is probably stated too strongly. The decay was only relative. A community, which could produce men of letters and philosophers in the third century A.D., was still vigorous; 
and that it was by no means so extinct as Mr. Petrie maintained, by the end of that century, is amply proved by the inclusion of Naukratis in lists of important towns and bishoprics of much later date, e.g. the Greek lists of Hierocles (early 6th cent.), and Leo and the Coptic List of Episcopal Sees, published (from two MSS.) by M. Amélineau as fourth appendix to his Geographie de l'Égypte a $l$ 'Epoque Copte. ${ }^{13}$ It is mentioned in the stories of two Coptic martyrdoms, ${ }^{14}$ and a merchant of the place plays a part in Heliodorus' Aethiopica, written late in the fourth century. The name does not occur, however, in any of the later Coptic Scalae (see Appendices to. Amélineau op. cit.), and we may therefore infer that Naukratis had lapsed by about the tenth century to a village, or rather to a group of villages, of which Nekrash, Gayif, and Nebireh survive.

\section{(1) The Hellenion.}

\section{C.-TOPOGRAPHY.}

Whatever the date of the first settlement by Greeks, no one has ever ascribed the foundation of the Hellenion by the nine cities of Asia to an earlier period than 570. The only question concerns its position on the site and its identification with existing remains. It may incidentally be remarked that Mr. Petrie, in his original publication, constantly assumed two things in regard to it which the text of Herodotus does not warrant, (1) that it was called the Pan-Hellenion; (2) that the market, presided over by the same nine cities, was held in its Temenos.

Mr. Petrie located the Hellenion in an area at the south end of the site, which he called the 'Great Temenos,' and drew certain historical inferences from the remains there observed, which were accepted by Mr. E. A. Gardner, and by scholars generally up to 1899 . In that year, as the main result of my first campaign on the site, I advanced the view that the Hellenion had nothing to do with the 'Great Temenos' at all, but was to be found in another Temenos at the north end of the Mounds-in the Greek quarter, in fact, not the Egyptian (B.S.A. v. pp. 42 ff.). In 1903, I was able (thanks to an unusually dry season) to continue the exploration of the northern Temenos, as far as the extreme limits of uncultivated land : but before the results are described a word must be said about the rival site, the 'Great Temenos.'

\section{(a) The 'Great Temenos.'}

One of my principal objects in returning to the site of Naukratis in 1903 was to probe for foundation-deposits which might show under what Pharaoh was built the immense Wall, described and mapped by $\mathrm{Mr}$. Petrie as surrounding his 'Great Temenos.' In the event I spent a week searching for its north-west corner, the only one whose position on Mr. Petrie's plan lay clear of cultivation or houses. I may say at once that not only did I never succeed in finding that corner, but-a most unlooked-for result-I never 
found any clear evidence of the existence of a Great Wall of any kind. As Mr. Petrie's benchmarks were no longer recognizable, and his plan had been somewhat roughly made, I could not lay down on my own chart the position of the invisible corner with any precision; and $I$ had to make wide casts for it from various sides. I first tried to hit the outer face of the north wall of his 'Temenos' by a series of pits pushed up from the north : then I tried to get the inner faces both of that wall and the western wall by a similar method from within the 'Temenos': then I tried for the outward face of the western wall, beginning far outside the possible area on the west, and advancing eastwards. In this way $I$ have no manner of doubt that $I$ completely traversed in several places the lines on which both the north and west walls ought to have been. But I never found any solid mass of brickwork of one-fourth the dimension ascribed by Mr. Petrie to his 'Great Wall.' What I did find was a much ruined complex of buildings, the lower of which were made of bricks of the dimensions recorded by Mr. Petrie in his Temenos Wall ; while the upper, surviving as one upstanding block in the very centre of the line in which the north wall of the Temenos was to be looked for, showed beneath their lowest courses a belt of earth containing pottery (including a few bits of Greek wares) not earlier than the fifth century B.c. The broadest wall actually lighted upon in these trials was one running north and south, measuring sixteen feet across: it formed the west side of a group of chambers, which had the character of a dwelling house. On every occasion on which I found a wall, chambers eventually opened on either hand of it, before a quarter of the requisite solid breadth had been revealed.

Since the cemetery mound on the south-west, which Mr. Petrie believed to be a surviving part of the Wall, was still there to guide me, it is not possible that I can have missed altogether the line of both the west and north walls of the Temenos as plotted by Mr. Petrie. Nor can it be supposed, in view of the antiquity which Mr. Petrie claimed for his Temenos Wall, that I was digging below its original site, and opening out chambers antecedent to its foundation. Therefore, with all diffidence (for it is almost impossible in such a case to prove an absolute negative), I must state my conviction that (for once) Mr. Petrie was mistaken in the nature of certain masses of construction, which exist on three sides of the area called by him the 'Great Temenos'; and that these represent not a solid. wall of brickwork, but an aggregate of house remains, piled up round a lower area, wherein lay the Egyptian temples and public buildings, of which one contained the Nectanebo Stcla, and another was excavated by Mr. Petrie himself and regarded as a Greek fort. This area was, in fact, the central area of the town, Pi-emrô. I make this suggestion with the better assurance since it does not appear from Mr. Petrie's own narrative that he ever tested the nature of these masses of construction by systematic digging. He seems (p. 24) to have relied mainly on the statement of local Arabs that there had been within their memory mounds on three sides of this area, as high as that surviving mound on the south-west, which he did not excavate for fear of disturbing modern graves. These other mounds, he says, were already reduced in 1884 to the 
general level. As for the high mound on the south-west, still surviving, this also appears to me, who have often examined it, not to be a solid mass of brickwork at all, but a nucleus of chambers, such as that $I$ found on the north-west. Mr. Petrie may have been deceived by the outcrop on its inner face of some continuous house-wall, now removed. In a word, I venture to assert not only that there is nothing answering to the Hellenion in this part of the mounds, but no Great Temenos at all. Probably there existed here small precincts of Egyptian deities ( $t o$ one of which the Ptolemaic pylon explored by Mr. Petrie gave access), surrounded by a high ring of mud-brick houses.

I trust it will not seem presumptuous if I say that at the time and under the circumstances in which a greater rigger than myself explored this area, such a mistake as I have supposed was well nigh inevitable. Indeed the mistake (if such it was) was acquiesced in by all Mr. Petrie's coadjutors and by myself in 1899. Although I had then every reason to transfer the Hellenion from this area, its superficial resemblance to a Temenos made me accept it without question as one great enclosure. In 1884, the deposit was much deeper over all the area. To follow the faces of the supposed enclosure walls could only have been done at great expenditure of time and money : to cut a test trench across or sink a pit upon the surface was probably to be confirmed in error: for the former was as likely as not to hit a broad wall which would continue along the axis of the trench; the latter to descend on to solid brickwork. Starting with the presumption that a great Temenos, other than those he had found in the north centre, must exist on the site, and having no reason to distrust a southern situation for this, Mr. Petrie could hardly help finding it in the vast southern quadrilateral hollow.

\section{(b) The Northern I'menos.}

The first part of the campaign of 1903 was devoted to the rival site on the north, the Temenos which I discovered in 1899, and identified with the Hellenion, because of its locality, the great size of its outer walls, and the occurrence within it of dedications not only to various individual gods, but

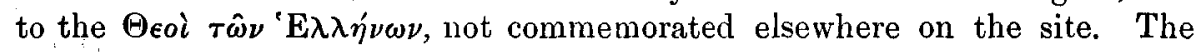
second exploration confirmed the conclusions of the first in three important respects. (1) I laid bare remains of the east wall of this Temenos, finding it to be of a breadth comparable to that already found on the west. (2) I again found dedications to the 'Gods of the Greeks,' and others in individual honour of Aphrodite, and (for the first time) Artemis. (3) I showed that the series of small chambers, opened in 1899, was continued eastward right across the Temenos by others belonging to the same periods, and similarly containing remains of dedicated pottery, the formulae on which seemed to indicate that distinct groups of chambers were devoted to distinct deities.

The excavations of 1899 had been suspended in their eastward course on the parallel bounding the horizontal series of squares IV (II on the 1899 
plan) on the east; and beyond that line, two or three trials only had been

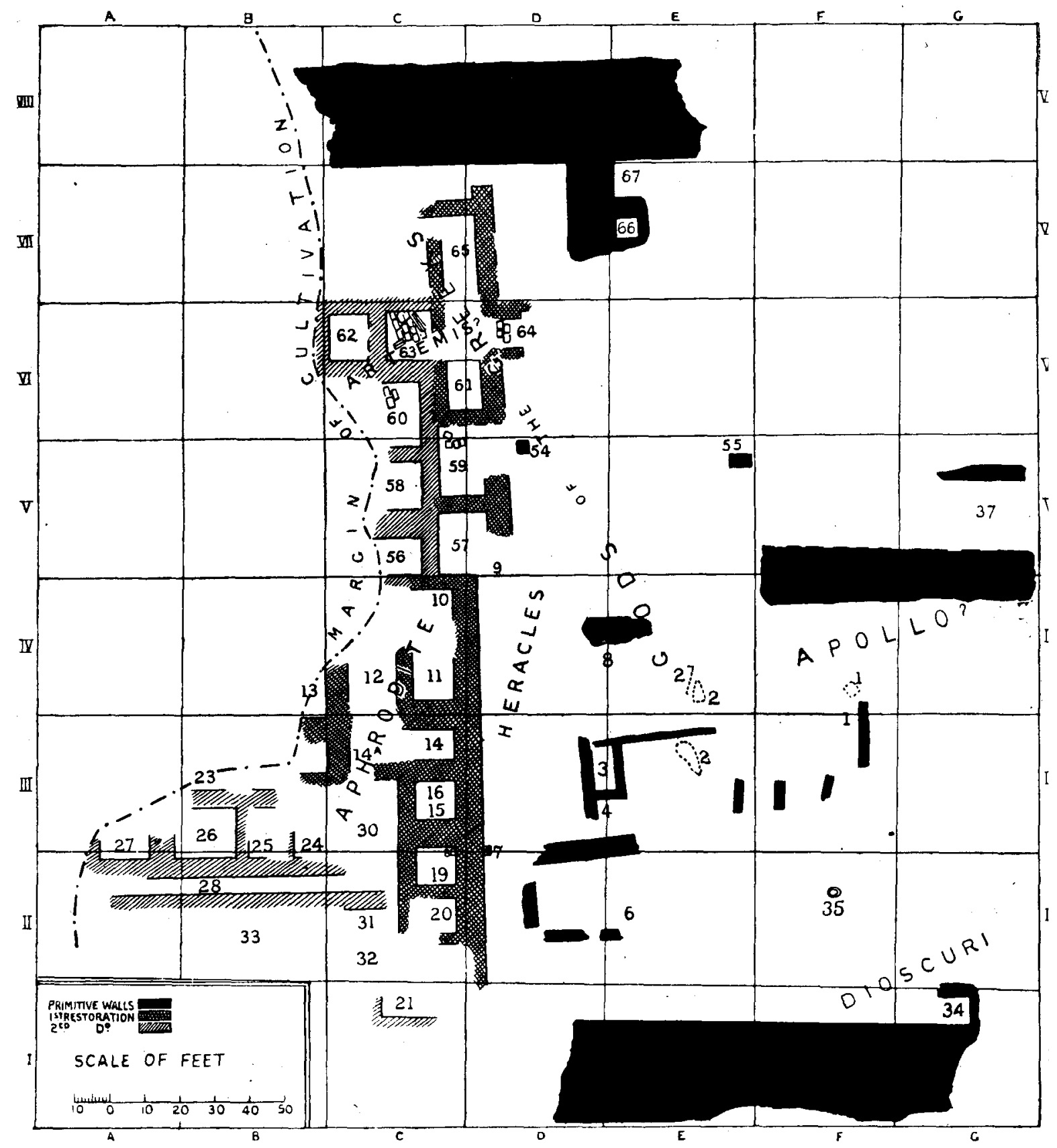

FIG. 1.-PLAN.

made which showed fragments of wall to exist (marked 54-55, 37 on the Plan, H.S.-VOI. XXV. 
Fig. 1). In 1903 I took that line ${ }^{15}$ as the left flank limit of an advance from south to north. It was useless, however, to begin this advance from any points nearer the south wall of the Temenos than those lying on the parallel dividing the vertical series of squares $F$ and $E$; for the area in the interval had been scooped out by sebakhin during the past four years below the original surface of the basal mud. Nor indeed were any but isolated patches of deposit left in the $\mathbf{E}$ and $\mathrm{D}$ squares.

The men on the extreme right flank of my line found themselves at once upon a broad wall, running north and south, the east face of which could not be clearly determined. A breadth of at least 25 feet was established, but this is by no means the whole dimension. This was unquestionably the eastern wall of the Temenos or Temple; for beyond it (as proved by repeated trials) dedicated sherds were not found, and the deposit seemed to contain only remains of houses. This wall, being based on the mud, belongs to the first construction. Its bricks are 14 inches long, and from 7 to $5 \frac{1}{2}$ inches broad. To the same period belong all the very scanty remains of walls found up to the parallel dividing E and D. Every later structure has been ${ }^{16}$ cleared away by sehakhin, and heaps of their refuse lie on the mud, from which some terracotta moulds and several bits of dedicated pottery, including the 'Herodotus' base (Inscr. No. 6), were recovered. In a small patch of undisturbed deposit, just west of 66, were found the fragments of the Horsemen Vase (Pl. V. 1) at a height of 10 inches above the basal mud.

The fragmentary range of chambers, next encountered on the north, was embedded in deeper patches of deposit, and the spaces 57, 59, 61, 64, 65, are all, in their existing disposition, to be ascribed to the same period as the earlier part of the Aphrodite Shrine, which was uncovered to west of them in 1899, i.e. the earlier part of the fifth century. For a uniform interval of deposit occurs under the lowest courses of their walls, averaging two feet in thickness and containing great quantity of sherds of early lucal and imported black-figured wares. Not till well above their foundation levels did red-figured ware occur, and then in fair abundance; e.g. the alditional fragments of the ' $\Sigma \tau \eta \sigma i \chi o p o v '$ kylix (p. 120) were found in the south doorway of 64 just above the bedded blocks there shown on the plan, which probably underlay a lost threshold stone.

This lowest stratum of deposit and the structural change which took place immediately after the latest period that it represents were seen best in chamber 63, which in its actual form, like all the range in which it occurs $(10,56,58,60,63,62)$, belongs to the Ptolemaic reconstruction. Here, after clearing the actual chamber, whose walls were preserved to a height; of

15 In the lack of surviving benchmarks of 1899, the filled-in well, marked 35 on the plan, served for a guide to my former bearings. So much had the area all about it been worked over again by sebakhin, that the month of this well, which had been left in a depression, was now elevated in a snrall mound.

16 Except one fragment of concrete paving 2 jt. above the mud level, which belongs to the first reeonstruction. 
about three feet, and finding in it red-figured ware ranging from the GraecoRoman period back to the third century B.c., fragments of Hellenistic terracottas and half a plaster antefix mask, we had (as in 1899) to hack through some feet ${ }^{17}$ of unproductive muddy sand, into which the foundation courses of the Ptolemaic walls were sunk two feet. Under this a stratum of squared stones emerged, so carefully bedded down as to look like a pavement, but showing no signs of footwear. Among these were two large fragments of rough stone gutters: several stones concave on one side, which looked like parts of a well-mouth; and the small stela, shown in Fig. 8. This was bedded down face upwards among, and flush with, the other blocks. In treatment it is exactly parallel to the 'Warrior Relief,' found hard by in 1899 (B.S.A. v. Plate IX. and p. 65), and, like it, was possibly a painted gravestone. Its mixed Egyptian and Greek style is interesting. Lying immediately under this bedding of stones was an Athenian silver didrachm of the archaic style of the early fifth centriry, and at precisely their level, but at a spot where the stone stratum failed, was found a terracotta representing the Infant Herakles. Some good red-figured fragments also occurred, at the same level. These stones proved to overlie two feet of early deposit like that observed to south of them-full of early local wares of many varieties, including several white-faced scraps with traces of painted dedications.

We were able both here and in 62 to clear the surface of the basal mud thoroughly, before too much water filtered in: but in 60 and 58 this conld not be so satisfactorily done. In 58, however, we succeeded in uncovering a patch of pavement of thin concrete, laid within two inches of the basal mud, and $\mathbf{5}$ feet 10 inches below the well marked floor level of the Ptolemaic restoration. On the Ptolemaic floor ${ }^{18}$ of chamber 10 was much fallen wall-plaster of brilliant blue.

The chamber last named, in which were found several Aphrodite dedications and (beneath the Ptolemaic floor) small terracotta heads of the type discovered so abundantly hard by on the west, seems to have belonged to the Aphrodite Shrine to west of it. The only intelligible dedications (besides those to 'Gods of the Greeks' which occurred in 57 and 63), found in the eastern chambers, were two (in 63 and 62, both in the lower stratum) showing parts of the name Artemis (Inscr. No. 8 and another not figured). From so small a number it would be unsafe to name this group the Artemis Shrine, more especially as one terracotta and two heads seem rather to indicate an ascription to Herakles, dedications to whom were found not far off in 1899 (B.S.A. v. p. 32 and Inscr. Nos. 3, 33, 84).

This eastern part of the buildings within the Temenos is continuous with the western, and, like it, has been entirely reconstructed in the early Ptolemaic period by builders who first heaped a mound of sand over beddeddown remains of earlier structures, belonging to the early fifth century.

\footnotetext{
17 This sandy stratum varies from 7 to 2 feet in thickness at different points.
}

18 Made of a concrete of lime, pounded brick, and pebbles. It was $\frac{3}{5}$ of an inch thick. 
These last had been erected upon remains of still earlier buildings, coeval with the first settlement of Greeks on this northern part of the site, a few traces of whose walls and pavements alone survive. The whole mass of remains belongs to an edifice, contained through all restorations within the same great enclosure walls, and apparently devoted to the worship of several individual gods and the 'Gods of the Greeks' as a whole. This it cannot. be doubtful was the Hellenion which Herodotus saw, and in which possibly he dedicated the vase whose base, bearing his name, came to light in $\mathbf{1 9 0 3}$ (Inscr. No. 6).

D.-Inscriptions (from the Hellenion site unless otherwise stated).

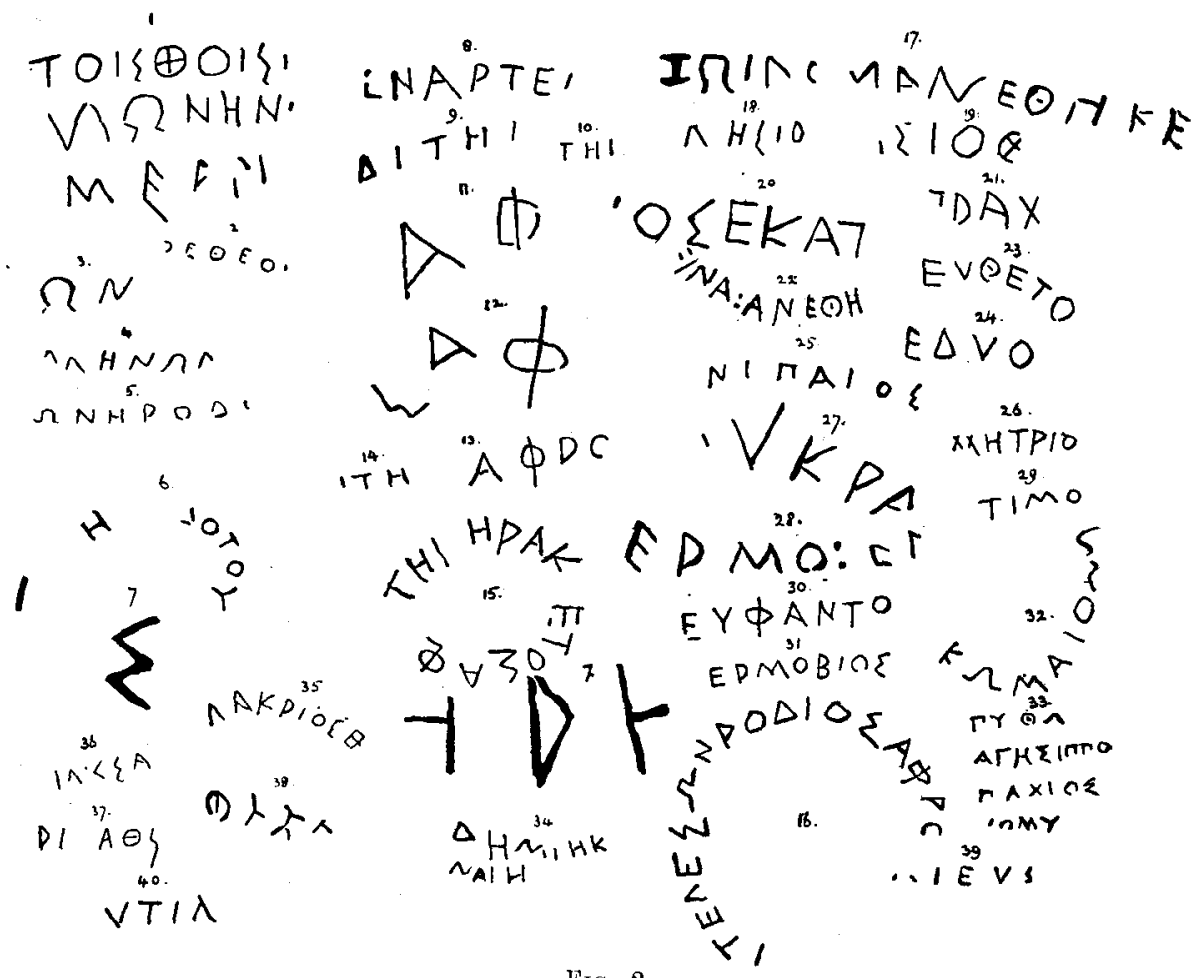

FIIx. 2.

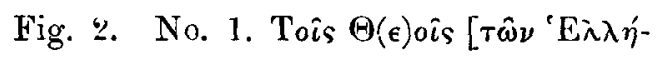
$\nu \omega \nu \mathrm{HN}[\ldots$.

$\mu \epsilon \dot{a}[\nu \dot{\epsilon} \theta \eta \kappa \epsilon \nu$.

2. ... $\dot{a} \nu \epsilon] \theta \epsilon \in \epsilon \hat{\imath}\left[\varsigma \tau \hat{\imath} \nu{ }^{~} E \lambda \lambda \eta^{\prime} \nu \omega \nu\right.$.

3. ..... $\left.\theta \epsilon \sigma \hat{\imath} \tau \hat{\omega} \nu{ }^{\prime} \mathrm{E} \lambda \lambda \eta^{\prime} \nu\right] \omega \nu$.

4. . ... $\left.\theta \epsilon \circ \hat{\imath} \varsigma \tau \hat{\omega} \nu{ }^{\circ} \mathbf{E}\right] \lambda \lambda \eta \eta^{\prime} \nu \omega \nu$.

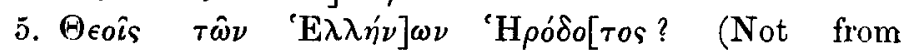
Hellenion.)

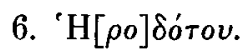


7. ... $\eta s^{\prime \prime} \mathrm{H} \rho \eta[\iota]$ : from untouched earth immediately S.W. of Mr. Petrie's 'Heraeum.'

$\left.8 . \ldots . a^{\prime} \nu \epsilon^{\prime} \theta \eta \kappa\right] \epsilon \nu$ 'A $A \tau \epsilon^{\prime}[\mu \iota \delta \iota$ ? The order of the words strongly favours the restoration of the name as Artemis.

9. 'A $\phi \rho 0] \delta i \tau \eta[\iota]$.

10. 'A $А \rho \circ \delta i] \tau \eta[\imath]$.

11. 'A $\phi[\rho \circ \delta i т \eta \iota$.

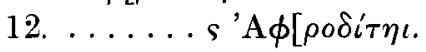

13. 'A $\phi \rho 0[\delta i \tau \eta \eta$.

14. 'A $\phi \rho \circ \delta] i \tau \eta[\iota]$

15. 'Н $\mathrm{A} \alpha \dot{\kappa}[\lambda] \kappa(\iota)$ тоs 'A $\phi[\rho \circ \delta \iota] \tau \eta[\iota]$.

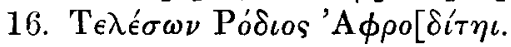

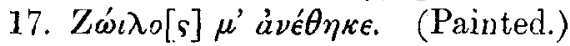

18. ......M $\left.\mathrm{M}_{\iota}\right] \lambda \eta \sigma i o(v)$. (Not from Hellenion.)

$19 . \ldots \mathrm{M} \iota \lambda \eta] \sigma i o(v) \theta\left[\operatorname{\epsilon o} \iota \varsigma^{\kappa} \kappa . \tau . \lambda . ~ ?\right.$

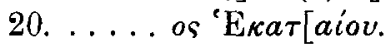

21. ?

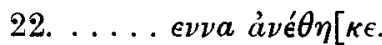

Women's dedications are very rare.

23. $\operatorname{Ev̀} \theta$ éto(v).

24. ?

25. ?

26. $\Delta \eta] \mu \eta \tau \rho l o(v)$.

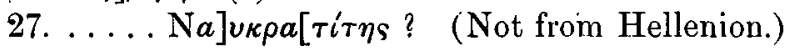

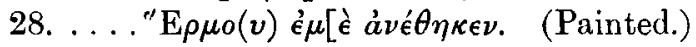

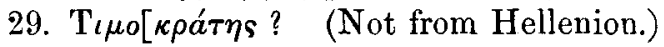

30. $\mathrm{E} \dot{v} \phi a ́ v \tau o(v)$.

31. 'E $\rho \mu$ ó $\beta$ เоs.

32. Kwraîos. (Only known as a surname of Apollo.)

33. Пú $\theta \omega[\nu$. (Not from Hellenion.)

'A $\gamma \dot{\eta} \sigma \iota \pi \pi \circ[s$.

Пáxios?

34. ? $\mathrm{E} \dot{v}] \delta \eta \mu i \eta \mathrm{K}\left[\ldots{ }^{\prime} \mathrm{A} \theta \eta\right] v a i \eta[\iota]$ ?

35. Complete. $\Lambda a ́ k \rho \iota s \theta^{\prime}$ ? cf. Nauk. ii. No. 819.

36. ?

37. ?

38. Cypriote. mo-ta-to-? Cf. B.S.A. v. No. 114 and Nauk. ii. No. 864.

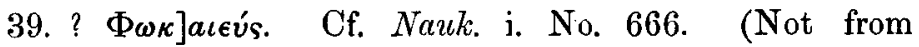
Hellenion.) On a fragment of $b . f$. kylix in finest style.

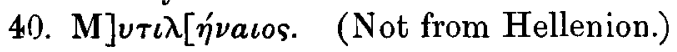

This is a selection, mainly from the Hellenion site, where dedicated 
sherds have most significance. About forty other inscribed sherds were found, many of them being scraps with only a letter or two. These it is not worth while to publish; but I may mention that four, obtained from children who raked over the rubbish heaps in the centre of the site about the Temenos of Apollo, contained part of dedications to that god. An amphora neck with a single Phoenician character, Shin, painted on it was found in the Hellenion. Two fragments of inscribed marble were brought to me. They read :

(a) White marble, extreme length 152 . (b) Coarse marble, broken on all sides. Lettering of third century B.c.

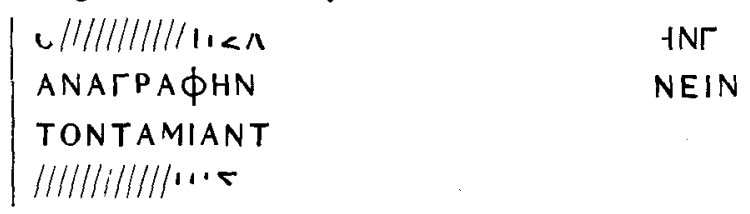

An ostrakon was sold me on the site, but I suspect it was imported from elsewhere. It is broken on all sides. It reads :

\author{
EYPEONH \\ $\triangle E N O B \wedge A B E C T W$ \\ PYMBEKA \\ ONTEח
}

D. G. H.

\author{
E.-POTTERY. \\ (By Miss H. L. Lorimer.) \\ [Plates V.-VII.]
}

THE excavations recently conducted at Naukratis have yielded nothing in the way of pottery that is, strictly speaking, new: considering the immense quantities of sherds found in the course of the earlier diggings, it would have been surprising if they had. None the less the fresh finds deserve mention, and that on several grounds. Recent discoveries in other quarters have shed light on the origin of some of the fabrics in question; and though these results are generally known, it is worth while to resume them in an account of what seems likely to be the last excavation of Naukratis. The discovery of late Attic r.f. ware in relatively large quantities, and the consequent possibility of dating with some precision the instructive gap in the series of Attic imports, are new facts, and have their bearing on the political history of the town. Finally, some few of the fragments are of sufficient beauty or interest to deserve publication on their own merits. 
The first steps towards dividing out the manifold fabrics of Naukratis among the various elements of its population were taken by Dr. Boehlau in his book Aus Ionischen und Italischen Nekropolen. The 'Rhodian' ware of Naukratis he claims on convincing grounds for Miletus, dividing it into an earlier style which does not employ incised lines, and a later, which combines incised with unincised zones of decoration. The excavations in Samos which form the starting point of his treatise have put beyond all doubt the Samian origin of the Fikellura fabric abundantly found at Naukratis and elsewhere. Of the mixed multitude, therefore, that inhabited the Graeco-Egyptian town, Milesians and Samians have come by their own. Simultaneously with the appearance of Dr. Boehlau's book Dr. Zahn published ${ }^{1}$ a couple of vase fragments from Klazomenai and pointed out their close resemblance to the later type of pottery from Tell Defenneh. Diumler ${ }^{2}$ had already drawn attention to the affinity of this latter fabric with the Klazomenian Sarcophagi, which are in all probability of somewhat later date: Zahn's sherds, which he considers to be contemporaneous with the Defenneh ware, supply several fresh points of contact. Among the most important characteristics common to the two styles are:-(1) the practice of painting in white immediately on the clay ground, and then surrounding the white wash with a brown outline, at least where precision of form was desired, as in the case of the human face, (2) the rendering of inner markings by the same brown paint on white and by incised lines on black paint, (3) the frequent use of rows of white dots, generally between two incised lines, by way of ornament, (4) the form of the horses and their ornamental harness. The Klazomenian fragments also belonged to a vessel, or vessels, of the hydria type common at Tell Defenneh.

It may, therefore, be regarden as fairly certain that the Defenneh ware is Klazomenian, probably imported, as Zahn holds, from the mother city. The first excavations at Naukratis yielded some fragments of this ware, but so few that both Professor Petrie and Dümmler regarded them as imports from Tell Defenneh, then generally taken to be the home of the fabric. Numerous sherds were obtained in the last diggings, and must be connected with the Klazomenian element resident in Naukratis. But as they agree minutely with the Defenneh ware, it is more probable that they too were imported than manufactured locally. It is true that not more than one or two fragments from Naukratis exhibit the elaborate technique of the best Defenneh ware, with its curious combination of outline, silhouette, and incising. B 102. 28 in the British Museum, on which are preserved parts of the figures of a hoplite and archer, is the best example of this style, which is only employed for careful and highly finished work. The large majority are of the inferior type also abundantly represented at Tell Defenneh, which bas abandoned the painted outline and employs white more sparingly, incises inner markings on black and white paint alike, and not infrequently makes an incised outline round the entire silhouette. It retains, however, the 
ornamental rows of white dots, the horse-trappings and saddle-cloths, and the type of male head with the great spreading beard characteristic of the more elaborate vases. No distinction can be drawn between the Naukratite and Defenneh specimens of this ware. ${ }^{3}$ The clay is grayish, as is also the case with Zahn's Klazomenian fragments, differing from the warm reddish colour of the best Defenneh vases.

Several of the fragments now in the Ashmolean Museum come from the shoulders of hydriae, and shew the method of construction in an interesting way. The neck, which joins the shoulder at an angle, was made in a separate piece and inserted in the body, the junction being covered by a clay fillet which was afterwards painted red. The same process was used in the case of the fragment in the British Museum 128. 1, which comes from Tell Defenneh and belongs to the inferior class of ware: the larger and finer Defenneh vases were made all in one piece, and the clay fillet which is characteristic of the whole series is merely ornamental.

How much farther the process of parcelling out the motley fabrics of Naukratis among her equally motley population may in the future be carried, it is of course impossible to predict.

Among the Attic b. f. fragments pieces of good early style are not wanting: ware of the Kleinmeister type however predominates, as in the case of the first excavations. But the trade relations of Athens and Naukratis, which must have lasted through a considerable period, were suddenly broken off. The total number of $\mathbf{r}$. $\mathrm{f}$. fragments of the severe period which the site of the latter town has yielded is exceedingly small, and those belonging to the Epictetic circle do not number more than two or three. Of those of severe style in the Ashmolean several seem to belong to a single vessel, the ' $\Sigma$ $\tau \sigma$ ' $\chi \circ \rho \circ \nu^{\prime}$ ' kylix in the style of Douris, a fragment of which was published in the Annual of the British School, vol. v. One of the more recently found pieces fits on to this fragment, which is therefore reproduced with this addition (Pl. VI. 5). Late r. f. ware on the other hand is abundant: there are some fine pieces, but most of it is of very inferior quality. Pieces of the still later stamped black ware were also found.

The event which broke off intercourse between Athens and Naukratis towards the end of the b. f. period, but before the new style had appeared, can have been no other than the invasion of Egypt by Kambyses; and the subsequent troubles of Athens herself may well have prevented the resumption of relations until the best days of the severe period were over.

The most interesting of the new fragments is that reproduced on Plate V. 1. It appears to be the wide funnel-shaped mouth of a bowl similar to Nos. 1 and 3 on Plate X of Naukratis, Pt. I, and is light and thin for its size. The clay was first covered with black glaze, and the field was then divided into panels by vertical lines of white and red paint enclosing a white zigzag line and dots. In each panel was painted in white the figure of a

3 Endt's statement (Ion. Vasenmalerei, p. 13) that incised outlines do not occur on the Defenneh ware is incorrect. 
man on horseback armed with a spear. The inner markings were put in with red paint and the whole background was washed over with the same colour: but to avoid coming in contact with the very absorbent white, the artist left a broad black margin round the figures. Groups of white dots were painted on the red background, and under the horses there are remains of a vegetable ornament, also in white. The division of the field vertically in the geometric manner is exceptional at Naukratis. This piece, both by the colouring employed and by the lightness of the fabric, recalls across an interval of many centuries the 'Kamares' ware of Crete, as does also, with curious fidelity, the polychrome internal ornament of the commonest early native painted ware of Naukratis. The resemblances may be accidental, but they are noteworthy when the singularity of the Cretan fabric is considered.

Of the remaining fragments the most noteworthy are the following :-

Plate VI. 1 : fragment covered with cream glaze: head in purple paint: inner markings given by reserved lines so fine as almost to produce the effect of incising. The head wears a close-fitting cap surmounted by a snake : a cloth hangs from the cap behind. On the famous Caeretan hydria at Vienna (Furtwaengler und Reichhold, Vasenmalerei, Pl. LI) Busiris wears a very similar cap, nudoubtedly intended, as Furtwaengler points out, to represent the uraeus head-dress of an Egyptian king. The present instance is a more faithful representation, for it preserves the hanging cloth, which is omitted on the hydria. This fragment may well belong to a scene from the Busiris myth. The way in which the cloth flies out behind suggests that the figure was in violent action.

Plate VI. 2. Fragment of unglazed clay : two figures and part of a third forming a procession. The first (fragmentary) carries a thyrsus with a ribbon attached; the second, a vase and wreath; the third, a thyrsus and what seems to be a wreath. The two complete figures also wear wreaths.

Plate V. 2. Shoulder of hydria of Defenneh type : three male heads.

Plate V. 3. Fragment of a flat plate decorated with zones of animals. The only complete animal resembles a jackal, and is represented in the act of turning, with a degree of realism very unusual in so conventional a scheme of ornament.

Plate VI. 3. Ware of Defenneh type. Satyr of Ionic type, playing double flute.

Plate VII. 1. Fragment found in the Hellenion : hawk perched on top of column or corner of building. Cf. Tanis, Part II., Pl. XXV. 1.

Plate VII. 2. Severe r. f. style: head of Dionysus, wreathed and slightly bearded : leopard on shoulder. In the field $\underset{\frac{1}{S}}{\stackrel{W}{S}}$ (i.e. some such name as $\left.\left[{ }^{\nu} A \lambda\right] \epsilon \xi \iota \varsigma\right)$ and vine leaf. 
Plate VII. 3, 4, 5. Severe r. f. style: the first two in all probability belong to the ' $\Sigma \tau \eta \sigma i x o p o \nu$ ' kylix (cf. Fig. 6 infr.) and the third closely resembles them both in style and in the thickness of the clay.

Plate VII. 6. A beautiful specimen of fine r. f. style: warrior with spear: inscription $10 \wedge \mathrm{EO} S$ : palmette ornament.

Plate VI. 4. Fragment of a white kylix in the style of Euphronios, represents the combat of Herakles and Apollo over the tripod. Portions of this kylix were found in the earlier diggings and are now in the British Museum (v. Hartwig, Meisterschalen, Pl. L). The new fragment was bought on the site by Dr. von Bissing (to whom thanks are due for a drawing from which the illustration in the text was made) and presented by him to the Museum at Munich; the British Museum has since acquired it by exchange.

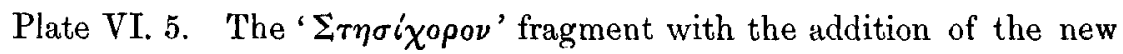
pieces.

H. L. L.

\section{F.-Actual State of THE Site.}

I HAVE implied that I consider the site of Naukratis to be now exhausted. This statement refers to the uncultivated part of it, the 'Mounds' proper, all whose superficial rubbish heaps I have had raked over repeatedly. There also I have cleared out all ancient wells I could find; but in $1903 \mathrm{I}$ got nothing from any of these, beside rough pottery, except a seated phallic terracotta, headless, and two stone horses and a stone 'sphinx' figure. The original town undoubtedly extended slightly to north and east of the limits of the actual $K u m$, and $I$ do not say that in the course of agricultural operations objects may not yet come to light, just as did the Nectarebo stela in 1899. But in this small extent of irrigated land very little can be expected to have survived. As for the Kum itself, I have satisfied myself that the deep temple areas are now all explored, and the shallower mounds to north-east, south-east, and west contain domestic remains very scanty in quantity and poor in quality. I also sank trial pits in both the hamlets which adjoin the site on the north. That immediately contiguous with the north-west corner of the Mounds seems to be built on an empty stratum of muddy sand some twelve feet thick: and so also, in spite of Mr. Gardner's observations (Nauk. ii. p. 11), did I find the second hamlet to be (er-Rushowan). My pits on the edges of its mound went down into masses of broken pottery and rubbish of all sorts, evidently ancient refuse heaps : my pits in its central part penetrated the same muddy sand as in the other hamlet without revealing the vestige of a burial. Both this mound and that on which the hamlet south of it stauds seem to me to be remains of the same old canal or river embankment, which crops up again under another hamlet further to north-west. I strongly suspect that the Nile flowed in antiquity past Nekrash and down the east face of Kum Gayif, crossing the eastern part of the area supposed to be a great Temenos by Mr. Petrie, wherein, near the bank, stood the Nectanebo stela. Thereafter it 
swept round the northern end of the mounds, past the Hellenion and between the two nearest northern hamlets, and so went away north-westward, leaving on its right bank the modern Ezbet er-Rashowan.

D. G. H.

\section{G.-Minor ANTIQUities.}

\section{(By C. C. Edgar.)}

Mr. Hogarth's last brief campaign at Kum Gayif was as fruitful as the former excavations in small antiquities of various kinds, corresponding to the variety of nationalities in the ancient town. Many of them were found in the trenches and wells-in which case they could mostly be dated approximately by external evidence-but the greater part, as usual, came from the small private hoards of the sebalkh-diggers. The painted vase-fragments have been studied by Miss Lorimer. I shall add a few remarks on some of the other objects, more especially on those which were taken as toll by the Cairo Museum and which I can describe from direct observation.

\section{1.-Unpainted Pottery.}

In Tanis, Vol. ii. Pls. 33-36, Mr. Petrie has published a large number of vases from the Stratopeda, partly Greek, partly Egyptian, and partly hybrid. The pottery illustrated below is of the same mixed character.

Fig. 3 shows a group of more or less complete vases from a well which Mr. Hogarth excavated in 1899. The two short-necked amphorae in the back row belong to a type which is characteristic of the Phoenician sphere of influence. It was in vessels of this form that the wine of Phoenicia was imported into Egypt, and that the water of the Nile travelled out in

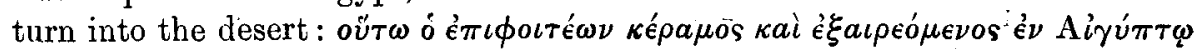

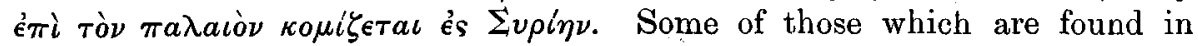
Egypt have Phoenician inscriptions on them. The one to the left in the illustration has three large letters painted in red on one side, but in this case they are Greek. The four larger jugs in the second row are typically Egyptian: note the rude Bes-head on one of the middle ones. The two smaller jugs are more Greek in style, though a similar form is found elsewhere in Egypt (e.g. Cairo Mus., Cat. Gén., No. 3031). As regards the date of this group it should be noted that the well in which they were found was faced with bricks, whereas the wells containing archaic Greek pottery were lined with large cylindrical tiles (much like the Mycenaean well at Phylakopi). Freiherr von Bissing, one of the few archaeologists who have studied the whole history of Egyptian pottery, tells me that in ihis opinion the native vases in the above group are not earlier than Cambyses, and 
D. G. HOGARTH, H. I. LORIMER, AND C. C. EDGAR

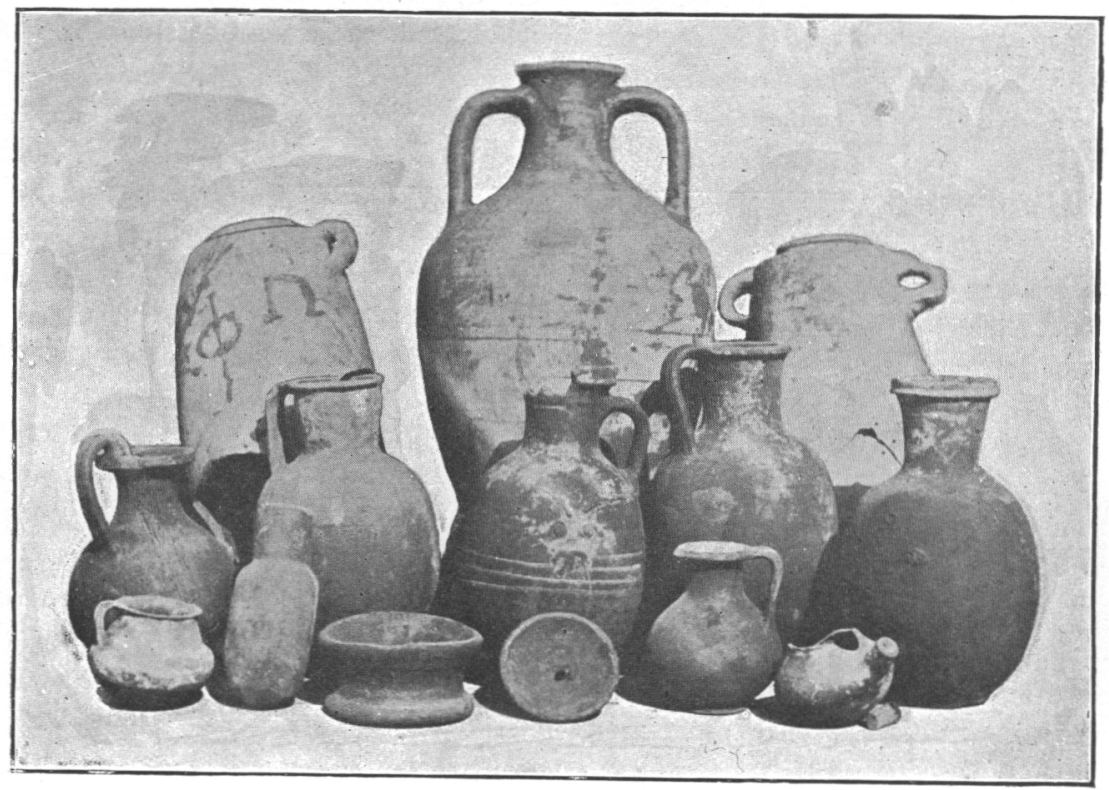

FIG. 3.

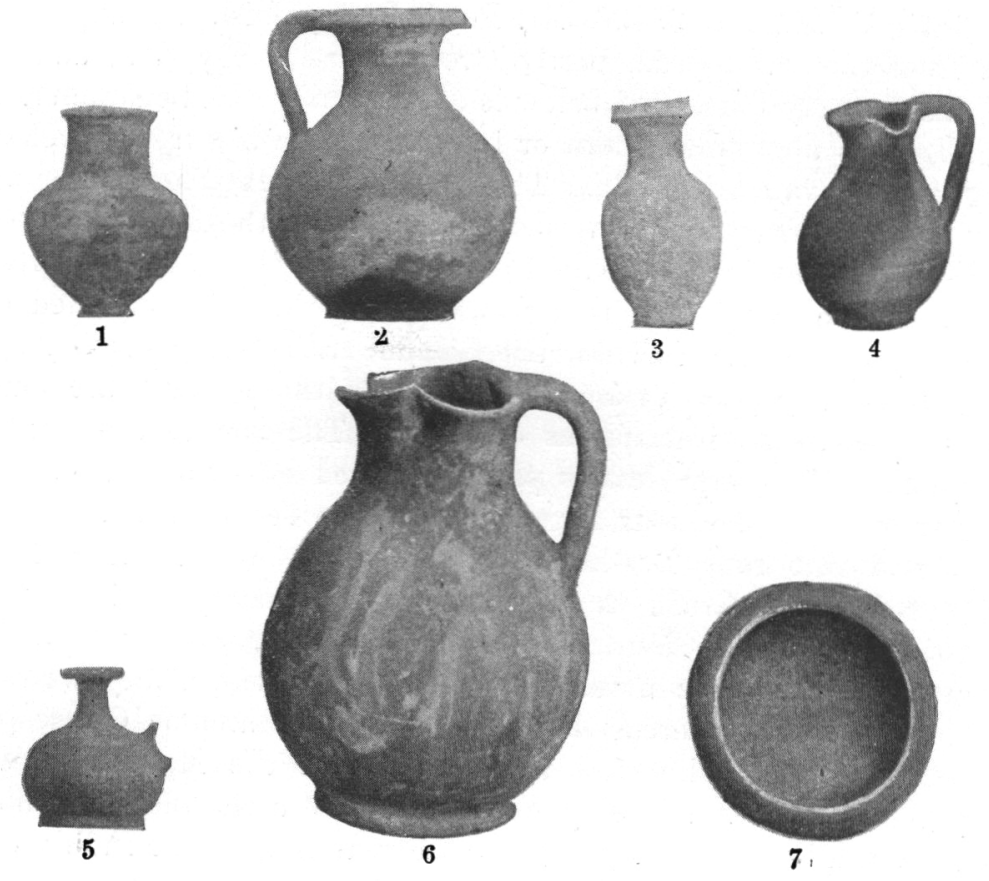

Fig. 4. (Scale $2: 11$.) 
probably not later than Alexander. The form of the large amphora points to the same period.

The contents of another well, excavated in 1903, are shown under Fig. 4. Nos. 1 and 3 are native types. Nos. 4 and 6 are typically Greek, but are made of ordinary Egyptian clay without any decoration. No. 5 is a black-glazed Greek vase. No. 7 on the other hand has a polished red surface. This well also seems not to have belonged to the pre-Persian town. It probably dates from the fifth century.

The next group, Fig. 5, comprises a few entire pots which were found in the neighbourhood of the supposed north-west corner of the Great

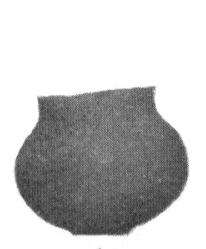

1
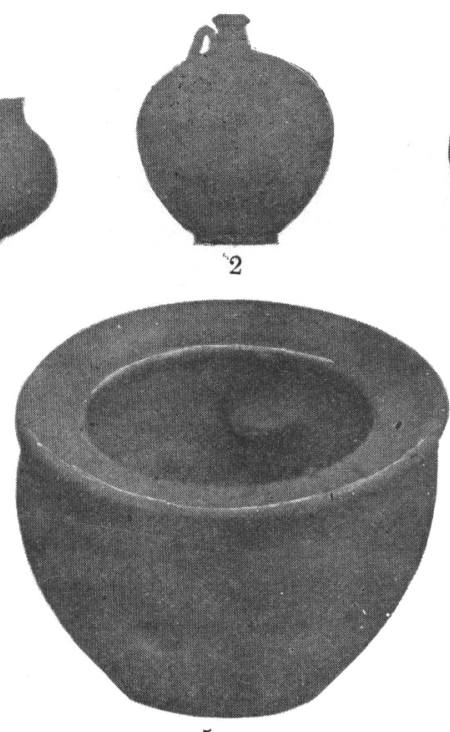

5
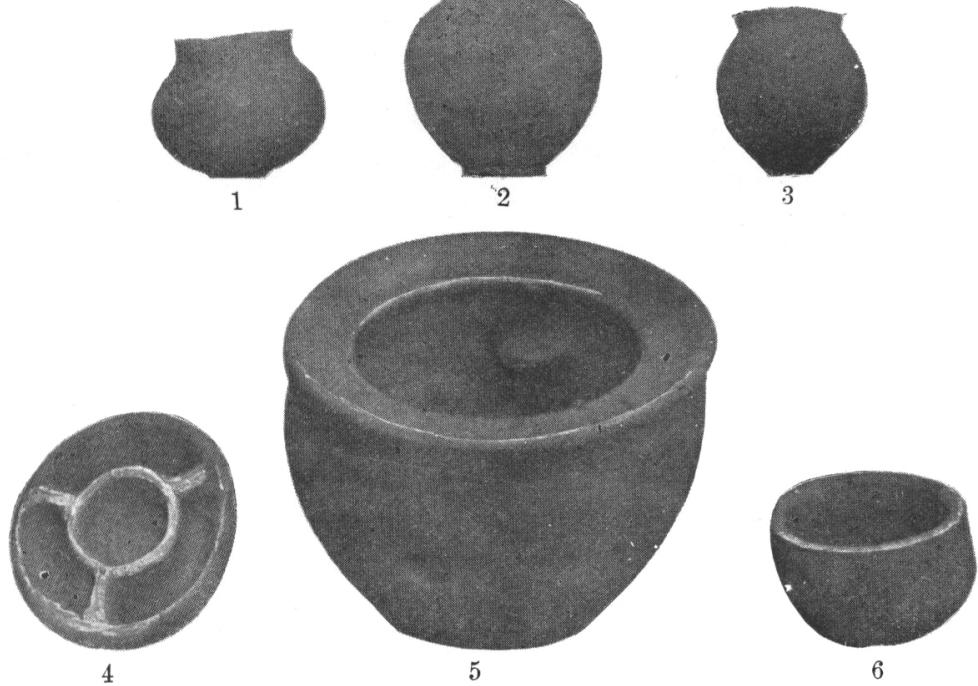

6

FIG. 5. (Scale 2 : 11.) No. 1 has had a handle, attached vertically.

Temenos wall (see Mr. Hogarth's article, p. $110 \mathrm{f}$ ). They may range from the seventh to the fifth century, but most of them are probably nearer the earlier limit: the few painted fragments which were got from the same trenches belonged to this period. They are made of ordinary red Egyptian clay, except No. 2, which is of light-coloured ware and is decorated with brown zones round the shoulder: this, as I learn from von Bissing, is a later Saitic type of vase. Nos. 1 and 3 may be compared with Tanis, ii. Pl. XXXV, Nos. 41 and 43. A vessel similar to No. 4 was found by Mr. Petrie at a level corresponding to the first half of the fifth century (Naukratis, i. p. 22). No. 5 has an inward-projecting rim, a ledge-handle on the inside, and a round hole, the purpose of which is not clear, on the opposite side rather low down (cf. Naukr. i. p. 42 and Tanis, ii. Pl. XXXIV. No. 26). All these vessels are Egyptian. The large amphora (Fig. 6) on the other hand is a foreign type and was probably not made in 
Egypt. The handles are flat. There are remains of letters on the shoulder in broad red lines, apparently Greek. This is another specimen of the vessels in which wine was imported into Egypt from the Aegean and the Orient. A third type, common in Cyprus as well as at Naukratis, will be found figured in Tanis, ii. Pl. XXXIII. No. 6.

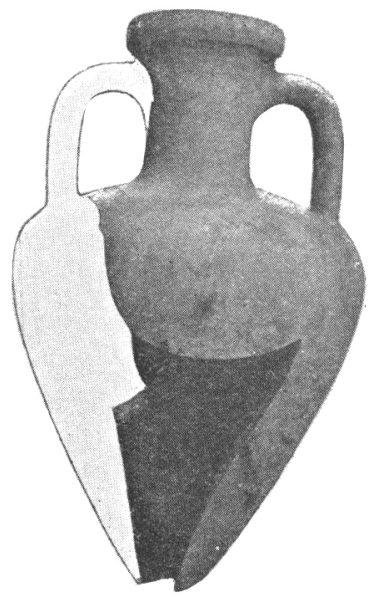

Fia. 6. (Scale $2: 11$.
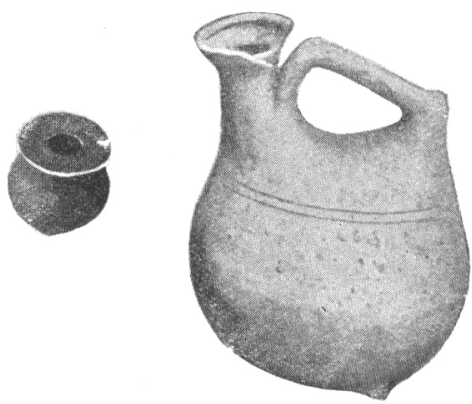

Fic. 7. (Scale $2: 11$.

The two vases shown in Fig. 7 come from the neighbourhood of the Hellenion. The askos, which has a ring-foot, is made of light-coloured clay. The other is of ordinary Egyptian ware: it has a flat top with a small hole in the middle, and tapers to a pointed base.

\section{2.-Seulpture.}

The little relief figured below (Fig. 8) was the largest piece of sculpture found in the last excavation. It is a rectangular block of limestone, $32 \times 28 \mathrm{~cm}$., with roughly flattened back. Its original destination is uncertain. Whatever it may have been intended for, it had afterwards been taken and used in the construction of what was probably a small shrine in the Hellenion. The few vase-fragments found below the floor of this building were all early, none being later than the sixth century ; those above the floor included some pieces of red-figured Attic ware.

In one respect the work is akin to Egyptian art. Fat men with walkingstaffs were a favourite subject in Egypt, the most famous being the so-called Sheikh el Beled in the Cairo Museum. On the other hand the style is not at all Egyptian: the pose is archaic Greek and the body is rendered in comparatively correct profile. As the surface is worn a good deal, especially about the head, the details are rather obscure. He seems to have worn a short garment, but it is difficult to make out. 
The figure is in low tlat relief with rounded edges. Another limestone relief from Naukratis representing a warrior with shield and spear, which was found in 1899 and which, like the present work, seems to have been used in the construction of a shrine in the Hellenion, is still flatter and has much sharper, square-cut edges. ${ }^{1}$ I thought at the time that it was a finished work of peculiar style, but this seems to me now less probable. The nearest parallel that I know of is a relief of a winged Egyptian goddess-equally flat and with still sharper edges-which was found along with some models and moulds from a sculptor's atelier at Memphis, and is in all probability an unfinished study. ${ }^{2}$ Possibly the warrior relief is the same sort of thing.

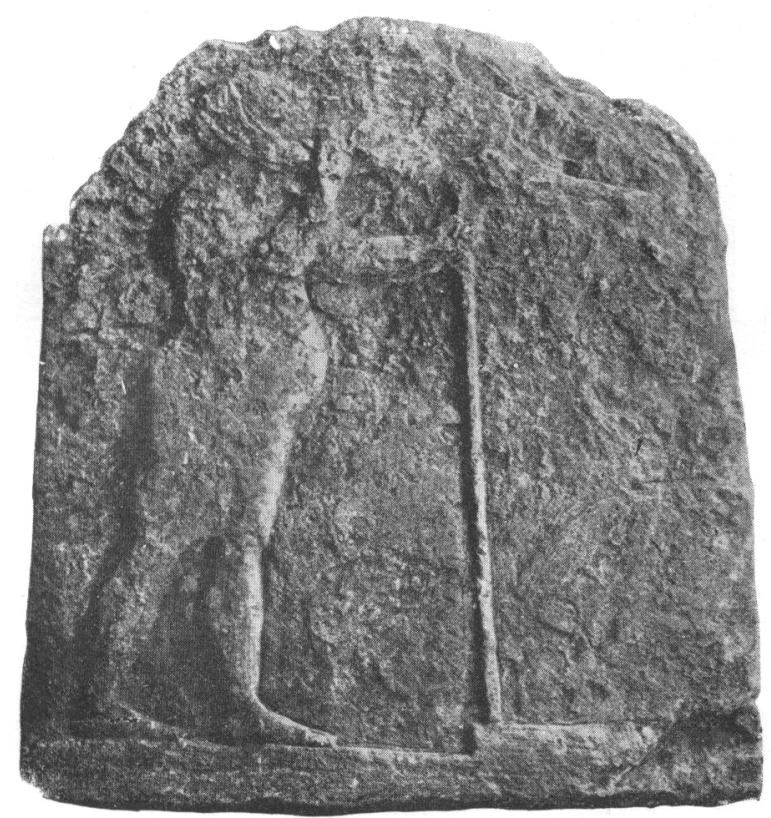

Fig. 8. (Scale $1: 4$.

Among the minor stone objects which are characteristic of the site, one of the most common is a representation of a naked woman lying on a bed, perfectly stiff and straight, with a child at right angles to her feet. The child is sometimes omitted. The woman usually lies on her left side with her left arm across her waist, sometimes on her back with her arms by her sides. The coiffure is always Egyptian, and indeed the whole figure is Egyptian work of a low class. Mattress and pillow are sometimes indicated. but more often left to the imagination. For specimens of the different varieties I refer the reader to Naukr. i. Pl. 19 and B.S.A. vol. v. Pl. XIV.

\footnotetext{
1 B.S.A. vol, v. Pl. IX.

2 In the Cairo Museum : Catalogue Général, No. 33413. Here and there in Egyptian tombs

and temples one finds imperfectly finished reliefs of similar appearance, e.g. in the mastaba of Ptahhotep at Sakkara.
} 
Mr. Hogarth's excavation produced the usual crop of these figures, some of which were found by him in the trenches.

Statuettes of the same type, some of them much more elaborately sculptured than the Naukratite examples, are fairly common in Egypt. Several are said to have been found in tombs, and it was perhaps for the requirements of the dead that the type was first invented. To place a statuette of this sort in the tomb of a dead relative was symbolic of providing him with a wife for the other world-a less barbarous form of piety than killing his widow. The marble idols which are found so frequently in the cist-tombs of the Cyclades are good examples of the same practice. With regard to the Egyptian statuettes M. Mallet, together with M. Maspero, ${ }^{3}$ has proposed a further explanation. As in Egypt the dead man was identified with Osiris, the appropriate consort for him would be a corresponding embodiment of Isis. M. Mallet thinks therefore that these small naked figures represented Isis rather than a mere human being. A point in favour of this view is that one or two of them wear the uraeus-circlet appropriate to queens and goddesses. The whole subject, however, needs closer study on the part of Egyptologists. One would like more evidence and information about their use as burial offerings.

One finds at Naukratis another class of naked female figures, carved in exactly the same style as the above-mentioned: a specimen from the recent

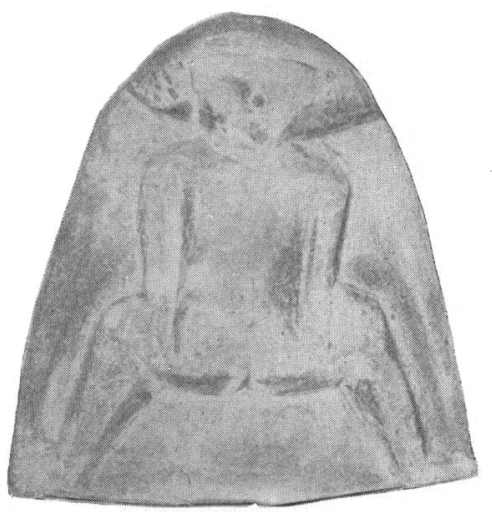

FIG. $8 \alpha$. excavation is shown in the accompanying illustration (Fig. $8 \alpha$; see also Naukr. i. Pl. XIX.). These figures are usually known by the name of Baubo. Baubo, according to the Orphic hymn, was the hostess of Demeter at Eleusis, and tried to amuse her guest by the same sort of gesture which the women of Egypt are said to have used on their way to the great festival at Boubastis. ${ }^{4}$ M. Mallet believes that the limestone statuettes really refer to this legend, and that the type was introduced into Egypt by the Greeks of Naukratis. But it is very doubtful whether there is any connexion between the Naukratite figures and this particular Greek myth. More probably the 'Baubos' had the same general significance as the other group of female figures, expressed in a still cruder image. We cannot say whether they (or the other type either) were used as burial offerings, as the necropolis of the period to which they belong has not yet been discovered. But as so many specimens of both types

3 Mallet, Les premiers établissements ; Maspero, Guide to Cairo Mus. (Eng. ed.), p. 296. Just lately there has come into the Museum from Mem lihis a figure of this sort holding a small Apis agaunst her bosom.

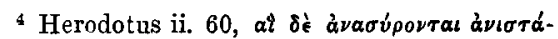

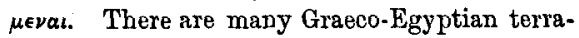
cottas in which this action is represented, but the figures which are commonly identified with Baubo are undraped. 
have been found scattered about the town (apparently not on the sacred sites), they at least seem to have been in request among the living inhabitants. It is very possible that they were regarded as charms, as indeed they are at the present day.

Except in a very few cases Mr. Petrie found no evidence for the dating of these statuettes. They seemed to him to belong to the sixth, fifth, and fourth centuries: one extremely rude figure he assigned to the end of the fifth. The recent excavations have thrown a little more light on this point. The 'Baubo' figured above was found in undisturbed ground near the supposed N.W. corner of the 'Great Temenos' in a distinctly early patch, most of its contents that could be dated belonging to the sixth century. In a neighbouring trench one or two of the 'child-birth' figures were obtained amid similar deposit. They may have gone on being manufactured for a long time without undergoing much change in style, but at any rate there is little doubt that they were common and popular in the sixth century B.c. In M. Mallet's opinion the 'child-birth' figures are in all probability Greek imitations of Egyptian types. It is possible that the individual workmen may have been Greek, or partly Greek, by birth. But however rude the style may be, it remains essentially Egyptian: several of the 'childbirth' statuettes from other parts of Egypt are rendered with an equal degree of carelessness, and one finds a similar type of head on some other minor Egyptian works. The 'Baubos' too are of the same character.

The sinall 'horsemen,' of which sufficient specimens have been already published (Naukr. i. Pl. 19 and B.S.A. vol. v. Pl. XIV), ${ }^{4}$ were no doubt made in the same workshops as the female figures. Mr. Petrie found one at Defenneh which he dated to the seventh century (Tanis, ii. p. 71): there is at least good reason for putting it before the middle of the sixth. One of those from Naukratis has a Greek inscription on one side which is probably a good deal later than this (B.S.A. vol. v. PI. IV, No. 58), but no doubt the manufacture of them lasted over a long period. The type in this case is certainly a foreign one. It is to be compared with the terracotta cavaliers of the archaic period, especially those from Cyprus. There are in Cairo certain terracottas from the neighbourhood of Boubastis representing mounted warriors with sharp-crested headgear and Asiatic beards. ${ }^{5}$ There is also in the same Museum a small four-horse chariot in limestone, done in exactly the same style as the Naukratite horsemen, and very possibly a Naukratite work: here again we are reminded of those Cypriote and Phoenician terracottas in which the same subject is represented. I may also call attention to another work of similar foreign character, a Jittle limestone group of a bearded man and a youth reclining at table: it comes

\footnotetext{
4 The riders are not always so incongruonsly small as on the published examples. On GraecoEgyptian terracottas the child Harpokrates is olten represented on horseback, but I do not think the small Naukratite cavaliers were intended, at least originaly, as images of Har-
}

H.S.-VOL. XXV. pokrates. I regard them rather as local, semiEgyptian reproductions of an imported type, like the charioteer mentioned in the text.

s I have lately seen fragments of exactly similar figures at Kum Gayif, and the same type occurs at Memphis and Bouto. 
from Sais and has been published by M. Daressy in the Annales du Service, vol. ii. Pl. II. The small head published below, Fig. 9, is superior in style to the works just cited and is probably an imported object from Cyprus : it has been part of a limestone statuette. It would be interesting to collect all the traces of Cypriote and Phoenician activity in Egypt. Certainly the part played by Cyprus in the development of Naukratis was very important.

Another group of limestone objects, very characteristic of Naukratis, consists of small phallic figures. These are probably in great part of the same age as the preceding types. A terracotta specimen was obtained along with the archaic horsemen from Boubastis mentioned above. They are often represented playing on some musical instrument, and some of them wear the side-lock of childhood. ${ }^{6}$ There is no reason for thinking that the type

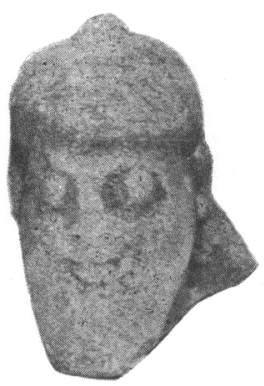

FIG. 9 .

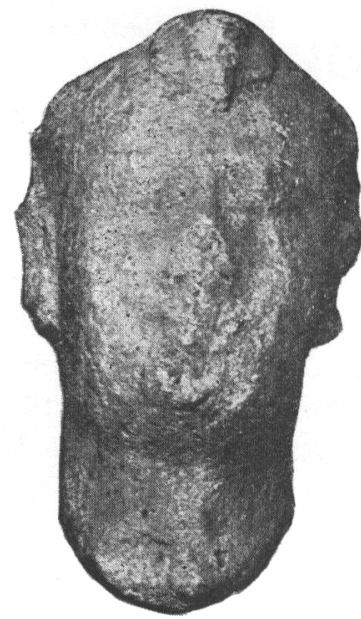

Fig. 10. (Scale 3:4).

was introduced into Naukratis from Greece. The style, such as it is, is Egyptian. In Leemann's Aeg. Monumenten, vol. i. Pl. XVIII., jllustrations are given of a number of phallic figurines of which No. 1466 is very like the Naukratis group which I speak of. The site, however, has produced

6 In this connexion it is worth noting that many of the later lerracotta images of Harpokrates have a phallic character. The intrusion of this element into the cult of the child-god has not yet been traced or explained.

The Naukratite figures are to some extent illustrative of a passage in Herodotus, ii. 45 :

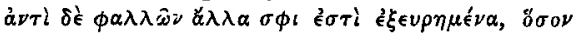

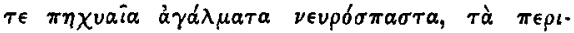

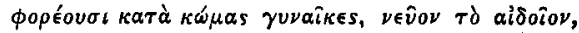

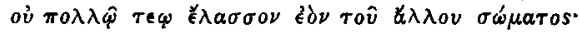

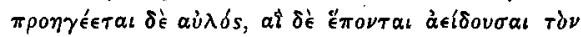
$\Delta \iota v^{\nu} v \sigma y$. There is a large terracotta of Egyptian style in the Cairo Museum (belonging to a group mentioned later on) which represents a procession of this sort: the chief personage holds a musical instrument and his phallos is supported by four women. 
a great quantity of indecent statuettes of various ages and in various materials.

Fig. 10 is a small plaster model of an Egyptian king's head which I picked up on a visit to Naukratis in 1901. Similar models are common enough in Egypt, and several others have been found at Kum Gayif. ${ }^{7}$ This one, however, is particularly interesting. Unlike most of the others it shows the upper part of the royal hood with the uraeus in front. While the face is practically finished, the ears and uraeus are merely roughed out. It is evidently a cast, made in a single, open-backed mould; and the state of the unfinished parts shows that it has been taken from one of those soft limestone models which one sees in Egyptian collections, and which usually have incised squares and measurements on the flat surfaces. I have tried to show in another place ${ }^{8}$ that, notwithstanding the common opinion championed by M. Periot, these squares are simply an application of the Egyptian canon of proportions, or rather of the later canon which came into use in the Saitic period. According to a credible tradition some of the early Ionian sculptors studied this canon in Egypt and introduced a similar rnethod of work into the Aegean. One cannot say, however, whether it was in Naukratis itself that they saw the system employed by Egyptian workmen, for the plaster models found there are perhaps all later than their time.

\section{3. -Terracottas and Moulds.}

The last excavation produced nothing so good as the group of female busts which were found in 1899 in the neighbourhood of the shrine of Aphrodite in the Hellenion. Of the ordinary archaic Greek types we obtained almost nothing except a fragment of a female figure holding a dove against her bosom in her left hand. Some interesting though far from beautiful fragments were found in one of the trenches near the north side of the 'Great Temenos.' On the evidence of stratification-especially of some Greek pottery which was found close by - they may be dated to the sixth century B.c. Three of these fragments (from three different figures) are reproduced below (Fig. 11). They belong to rather large statuettes of coarse fabric, made solid, with flat backs. The largest piece is part of a naked female figure. The head is remarkable for the way in which the lips are stuck on, while another head from the same find has the hair represented by small impressed circles. The latter peculiarity I have noticed on several terracottas from Memphis and Boubastis which are likewise made solid, but whether these have any direct connexion with the present group I cannot as yet say for certain. Some of them are distinctly Egyptian, and it need not be supposed that the Naukratis fragments are Greek work.

From the Hellenion area came some fragments of a fairly large figure of good Greek style representing the infant Herakles strangling the serpents.

\footnotetext{
7. Naukratis, i. Pl. 17, No.2. An 'archaic head of hard limestone' reproduced in Naukr. ii. Pl. 17, No. 13, looks like another of these

models.

8. Recucil de Tra:aux, forthcoming number.
} 
We obtained the usual number of Hellenistic female heads like those of the Tanagra statuettes. Many of these were certainly made in Egypt, as could be seen from the clay, and no doubt there was a manufactory of them in Naukratis itself. The Satyr on the wine-skin in the Cairo Museum-one of the very finest of Hellenistic terracottas-is said by M. Maspero to have been found near Kum Gayif ${ }^{9}$ and is very probably therefore a Naukratite work. As regards the later types, the ordinary statuettes of the Roman period, it is sufficient to say that they are as plentiful in Naukratis as in other Egyptian towns. The only one I need mention is a fragment of an irrigation scene representing a man working the Archimedean screw. ${ }^{10}$

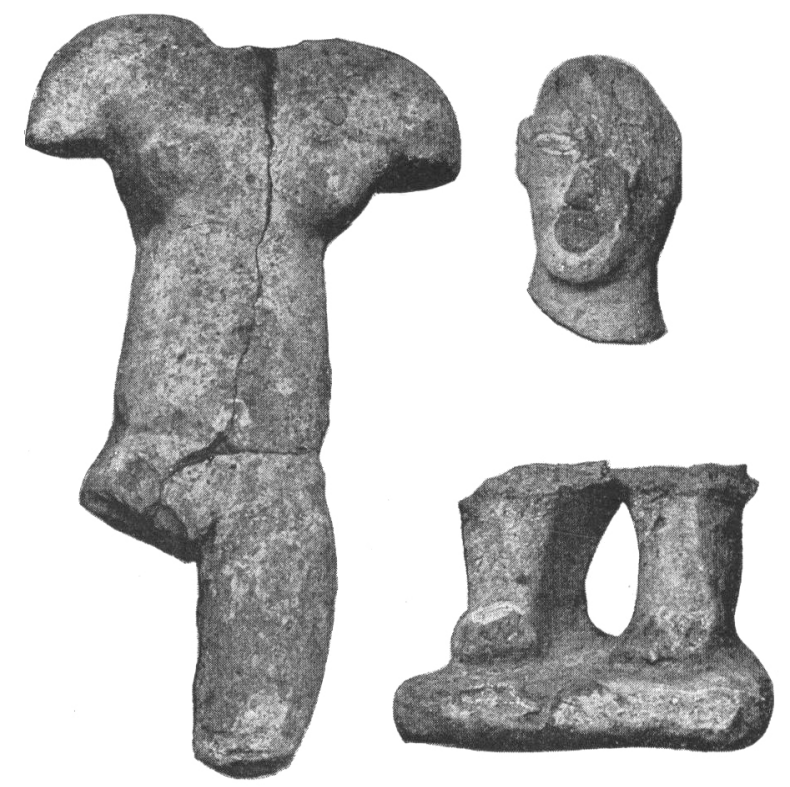

FIG. 11 .

That terracottas were made at Naukratis is proved beyond doubt by themoulds which Mr. Hogarth found there. They came from the top rubbish at the N.E. end of the site. One of the best of them, now in Cairo, is reproduced in Fig. 12. Like all the others it is made of ordinary Egyptian terracotta. The outside is ronghly smoothed down. The right side of the mould is broken. As can be seen from the photograph, the subject is a female figure of Hellenistic style (like some of those from Tanagra) with a mantle draped across the front of her body. Head and hands have been made separately: the face at least would probably be done in a mould. The back was, no doubt, more or less plain, perhaps a mere rough wall made by hand. The edges of the mould are quite sharp: it is evidently not part of a piece-mould.

9 Guide to the Cairo Mruseum, 1903, p. 354.

10 For a complete example of this type see
Bulletin de la Soc. arch. d'Alexandrie, No. 7 p. 44. 
In material and technique Fig. 12 belongs to the ordinary type of mould used in Greek countries for the fabrication of terracottas. There are many similar specimens from Greece, Asia Minor, and Sicily, and a few others from Egypt. Where this type of mould was used, if a figure had to be made in several sections, each section was pressed in a single separate mould, and the parts were afterwards joined together by hand. But most of the moulds for terracottas found in Egypt are of a different type from this. ${ }^{11}$ They are piece-moulds, usually of two parts, and the edges of the sections are fitted together by mortises and tenons: probably the two parts of the terracotta were first attached to each other by the two sections of the mould being pressed together, the junction being afterwards completed by hand. Another peculiarity is that they are for the most part made of plaster instead of terracotta. The ordinary Graeco-Egyptian terracottas of the Roman



Fig. 12. period were made in moulds of this form, whether of clay or of plaster. At

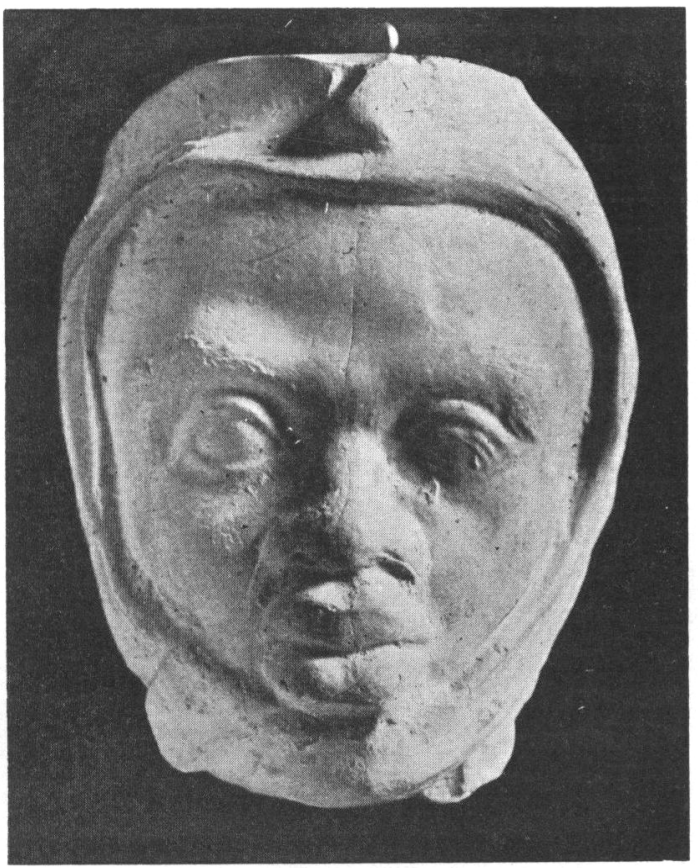

F1G. 13

${ }_{11}$ Catalogue Général du Mus. du Caire: Greek Moulds, p. xiii ; Vorzeichniss der Aeg. Altertümer (Berlin), p. 373. 
what date the type was introduced we cannot say, but it seems probable that the ordinary Greek type, such as we find at Naukratis, was still in common use in the Hellenistic period. ${ }^{12}$

The best of the other moulds found by Mr. Hogarth was a large negro's face, now in the Ashmolean Museum: Fig. 13 represents a cast from it. It had broader edges than Fig. 12, but was not part of a piece-mould proper. Another complete specimen, left in Cairo, consisted of the front part of a bull's head with a sort of rosette above the forehead. In technique it is similar to Fig. 12.

\section{4.- Miscellaneous Objects.}

Very little bronze was found in the last campaign. The best piece, very good of its kind, was a small Egyptian figure of Bes playing the lyre: it is now in Cairo. The scarabs were chiefly of the local blue-glazed faience, and terracotta moulds for shaping the backs of them were still to be picked up in abundance from the rubbish heaps near the scarab factory. One of the trenches at the South end of the site produced a great quantity of small faience objects of the Saitic period, but they were much injured by the dampness of the soil and comparatively few were worth keeping. Most of them were small figurines of well-known types--sows, Thoneris, the god Shu, etc. No doubt they were made in the local factory. Among the faience objects from other parts of the site I may mention a fragment represeuting the forepart of a lion with open mouth; the tongue had been coloured red; the ears were of the schematic Egyptian type. Parts of little figures like Naukr. i. Pl. 2, Nos. 10, 17 were also found. New Year bottles with necks in the form of lotus and papyrus were represented by numerous fragments. ${ }^{13}$ I also noticed one or two fragmentary specimens of hedgehog-vases. ${ }^{14} \mathrm{Mr}$. Petrie considers that the factory had passed into Greek hands before the accession of Amasis. No doubt a fabric in such a place as Naukratis would be specially subject to foreign influence, and it is very possible that some of the strangers, whether Ionian or Cypriote or Phoenician, took up the manufacture. But if so, they must for the most part have confined themselves to reproducing the Egyptiau types, for after all the number of faience objects of un-Egyptian appearance found at Naukratis is very small compared with those that are entirely Egyptian. I am referring of course to the early period only. Of later genuinely Greek work in the same material a great many fragments have been discovered on the site, as for instance pieces of vases with female figures in relief: it is very probable that there was a fabric there in the Ptolemaic period. The finest Greek work in blue glaze that I know of is a

12 Pernice, Jahreshefte, 1904, p. 154, gives some interesting information and stugrestions about the sort of moulds used in making Greek bronzes. It is very possible that the methods of the coroplastae were in various centres influenced by those of the bronze-casters or the other way about. I hope to return to the questions about the bronzes some other time.

13 Cf. Bissing, Fayencegefässe (Cairo Catalogue), p. Xv.

${ }^{14}$ Cf. op. cit. p. $\mathrm{xxv}$. 
head from Naukratis in the British Museum, the portrait of a Ptolemaic queen (Naukr. ii. Pl. 17, No. 11).

The small object figured below (Fig. 14) seems to be a comb of limestone with a handle in the form of a human head. It came from the sebakhin and was presumably found on the site. It has an odd resemblance to certain combs and pin-heads of bone, ivory, and stone from the prehistoric finds in upper Egypt (cf. Naqada and Ballas, PJ. LIX).

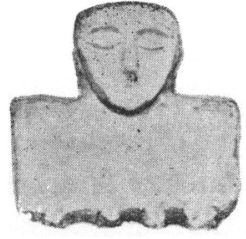

FIG. 14.

\section{5.-Conclusions.}

The antiquities of which I have given the above desultory description do not by themselves throw any new light on the early history of Naukratis.

The finds at the South end of the site consisted for the most part of Egyptian material, such as faience objects and native pottery (see Mr. Hogarth's remarks above, p. 107). Several fragments of imported amphorae like Fig. 4 were found, but of painted Greek pottery there was scarcely anything. This confirms our previous belief that in early times the South end was the more Egyptian part of the town. It is also a minor argument against the view that the 'Great Temenos' is to be identified with the Hellenion.

The area at the North end, where we have placed the Hellenion, chiefly on the ground of so many inscriptions to the 'Gods of the Hellenes' having been found there, has now been tested to the bottom level wherever it was practicable. The antiquities from this area are almost all Greek, including a great deal of sixth century pottery.

Professor Petrie's work at Naukratis proved beyond doubt that the site was inhabited long before the time of Amasis. But even in the seventh century the town was not a purely Greek settlement. It was at least partly Egyptian. Native artisans worked and lived there. That the Cypriotes had a footing in the place from a very early period is almost certain. The engraved tridacna shells, which are found scattered along the routes of Phoenician trade and of which so many specimens come from Naukratis, indicate that the Phoenicians too had a direct or indirect connexion with the town : it may have been at one period a port of call for Phoenician ships.

Unless the testimony of Herodotus is entirely baseless (which probably no one will maintain), the town suffered a great reorganization and extension under Amasis. According to Herodotus it was that king who gave the Greek traders sites for building altars and temene, of which the largest was the Hellenion. The main questions still in dispute (from the archaeological point of view) are whether any of the temples were founded before the time of Amasis and whether the antiquities from them, particularly the inscribed and painted pottery, are in part earlier than 570 B.c. Endt, Ionische Vasenmalerei, p. 68, adopting the conclusions of Hirschfeld without question- 
ing, accepts this late date for the Naukratite pottery. ${ }^{15}$ When writing of the finds from the 1899 excavation I expressed a somewhat similar opinion (B.S.A. vol. v). The excavations of Boehlau in Samos have shown that some early Ionian types were still popular in the second half of the sixth century. Still, if the dates which are generally accepted by archaeologists about early Greek pottery are right, it seems very doubtful whether all the fragments from the Naukratis temples can be as late as 570. As the literary evidence is not in itself decisive, there is at least a probability that some of the temples, especially that of the Milesian Apollo, date from the earlier days of the town. But most likely the Hellenion was a later foundation: its situation is less central and the finds from it are less archaic. One may reasonably suppose that this, the largest and most famous of the Greek temene, was built when the town was resettled by Amasis and that from this period dates the importance of the nine combined states, - of one of which, it must be remembered, Herodotus was a citizen.

Cairo, 1904.

C. C. E.

15 The same paragraph contains some curious information about the founding of Daphnae (p. 69). 